\title{
Solid Organ Transplant and Parasitic Diseases: A Review of the Clinical Cases in the Last Two Decades
}

\author{
Silvia Fabiani ${ }^{1,2}$ (D), Simona Fortunato 2 (D) and Fabrizio Bruschi ${ }^{2,3, *(D)}$ \\ 1 Infectious Disease Department, Azienda Ospedaliera Pisana, 56124 Pisa, Italy; fabiani.silvia@libero.it \\ 2 School of Infectious Diseases, Università di Pisa, 56124 Pisa, Italy; simona.fortunato13@gmail.com \\ 3 Department of Translational Research, N.T.M.S., Università di Pisa, 56124 Pisa, Italy \\ * Correspondence: fabrizio.bruschi@med.unipi.it; Tel.: +39-050-221-8547
}

Received: 21 March 2018; Accepted: 18 July 2018; Published: 31 July 2018

\begin{abstract}
The aim of this study was to evaluate the occurrence of parasitic infections in solid organ transplant (SOT) recipients. We conducted a systematic review of literature records on post-transplant parasitic infections, published from 1996 to 2016 and available on PubMed database, focusing only on parasitic infections acquired after SOT. The methods and findings of the present review have been presented based on the Preferred Reporting Items for Systematic Reviews and Meta-Analysis (PRISMA) checklist. From data published in the literature, the real burden of parasitic infections among SOT recipients cannot really be estimated. Nevertheless, publications on the matter are on the increase, probably due to more than one reason: (i) the increasing number of patients transplanted and then treated with immunosuppressive agents; (ii) the "population shift" resulting from immigration and travels to endemic areas, and (iii) the increased attention directed to diagnosis/notification/publication of cases. Considering parasitic infections as emerging and potentially serious in their evolution, additional strategies for the prevention, careful screening and follow-up, with a high level of awareness, identification, and pre-emptive therapy are needed in transplant recipients.
\end{abstract}

Keywords: parasitosis; solid organ transplant (SOT); post-SOT parasitic infections

\section{Background}

Solid organ transplantation (SOT) is a life-saving procedure, but it does not lack short-term and/or long-term risk. Despite continued improvement in the clinical management of SOT recipients, infections still represent one of the leading causes of morbidity and mortality in this population.

SOT recipients can develop bacterial, fungal, viral, and/or parasitic infections. Although the prevalence of parasitic infections in SOT recipients was lower than viral, bacterial or fungal [1], in the last decade, there has been a growing identification of parasitic infectious diseases occurring in transplant hosts both in endemic and non-endemic settings for the specific parasitosis [2] (see Figure 1). This is probably due to more than one reason: (i) the increasing number of patients transplanted and then treated with immunosuppressive agents; (ii) the "population shift" resulting from immigration and travels to endemic areas, and (iii) the increased attention directed to diagnosis/notification/publication of cases.

Most of the data was published by European and North American Countries.

Parasitic diseases may affect transplant recipients as a result of (i) transmission by transplanted organ (or blood product, either before or after transplantation); (ii) reactivation or recrudescence of latent infections in the previously infected recipient; (iii) de novo infection in the post-transplant period by means of natural infection $[2,3]$. 


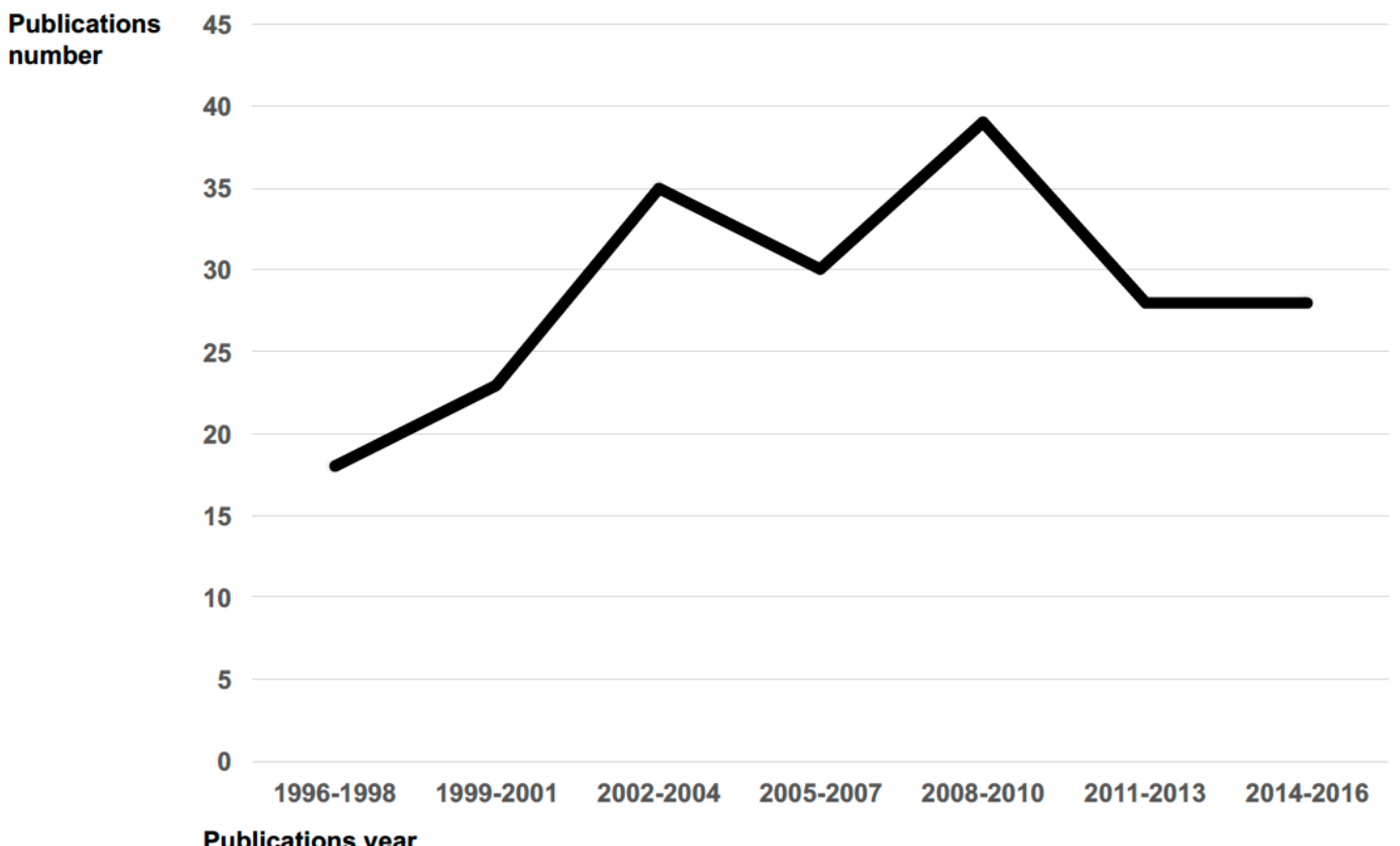

Figure 1. Publications number trend on parasitosis in SOT recipients per period 1996-2016.

Reactivation of a dormant infection occurs as a consequence of immunosuppression which in transplanted subjects, is induced by drugs required to induce immunosuppression in early phase and to maintain immunosuppression in the late phase or to treat organ rejection. Different therapeutic strategies are nowadays available: corticosteroids, antibodies, calcineurin inhibitors (CNI), anti-metabolite agents and mammalian target of rapamycin inhibitors (mTORI), depending on the protocols used by the different transplant centers, distributed worldwide. The optimal level of immunosuppression in SOT is a delicate balance between the rejection's prevention and the immunosuppression's side effects. As a consequence, all SOT recipients need an individually tailored immunosuppression regimen [3].

\section{Objectives}

We conducted a systematic review of literature records on post-transplant parasitic infections, published since 1996 to 2016 and available on the PubMed database, to analyze the occurrence of parasitic infections in SOT recipients.

\section{Materials and Methods}

The methods and findings of the present review have been reported based on the preferred reporting items for systematic reviews and meta-analysis checklist (PRISMA). Figure 2 provides a flow chart of the procedure used to collect information for the present review.

We searched the literature on PubMed library combining the term "solid organ transplant" or "SOT" along with the name of parasite genus or disease. The PubMed database was searched for papers published from 1 January 1996 to 31 December 2016.

No language restrictions have been used.

Two investigators (SF, SF) independently reviewed the retrieved articles in two stages; first assessing relevance from the title and abstract and if relevance was still unclear, the full text was read. Any disagreement about inclusion was referred to a third reviewer (FB) and resolved by discussion. From each eligible document, data were collected in predefined tables. The predefined tables summarizing individual cases included age, gender, Country of origin and/or nationality, and 
reported risk factors (e.g., immigration/travel history) for both donor and recipient of SOT, manner of parasitic acquisition, type of transplanted organ, type of immunosuppression, parasitic disease onset from transplantation, diagnosis of parasitic disease by clinical features, imaging and laboratory, parasitic disease treatment, outcome, and reference.

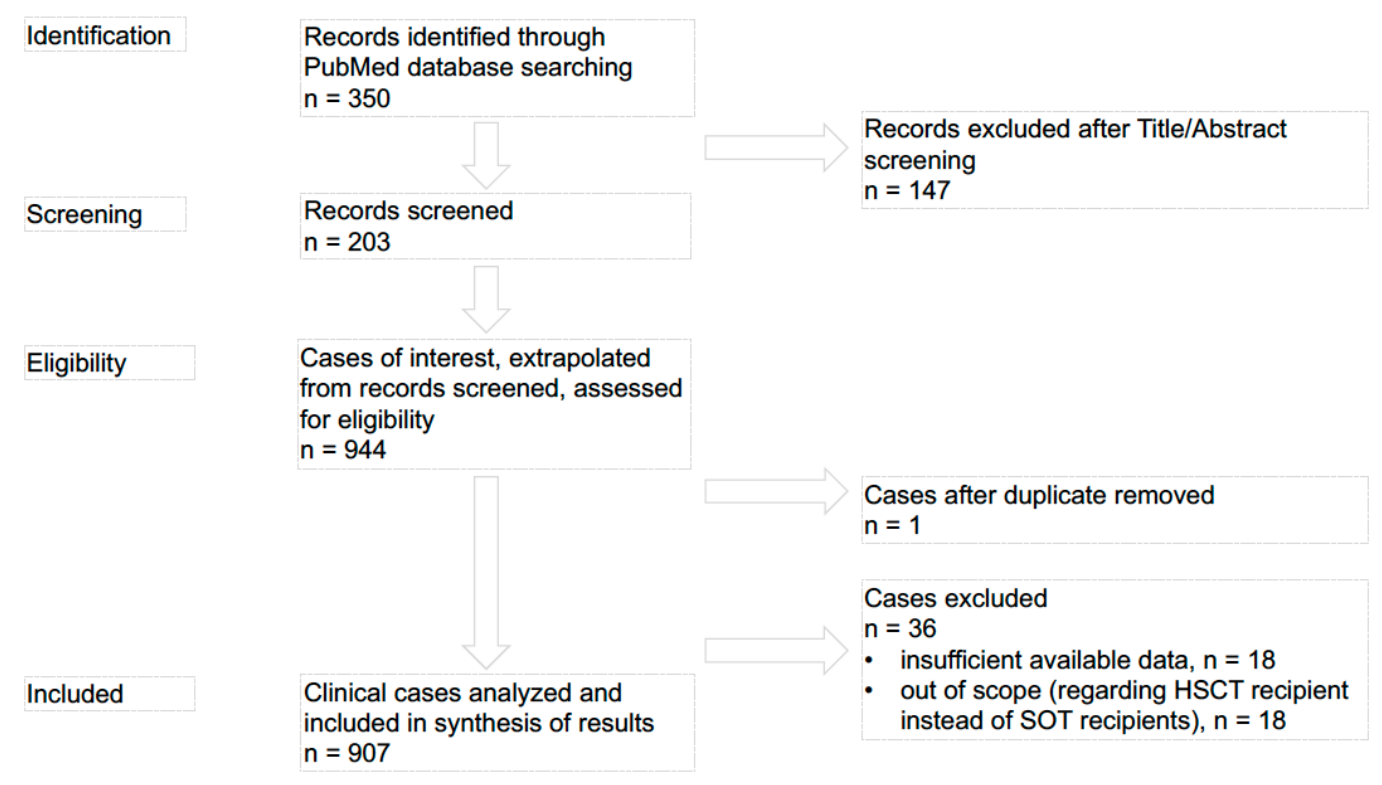

Figure 2. PRISMA flow chart: data collection and selection of studies.

Papers were excluded if at least one of the following criteria were present: (i) records did not regard parasitosis in SOT recipients; (ii) transplant of known infected organ; (iii) studies published before 1996 or after 31 December 2016; (iv) studies reported insufficient data, required to complete predefined tables.

In cases where the existence of duplicates was probable, according to anamnestic, laboratory and clinical data, cases were only presented once. Descriptive analyses and graphics were performed in Excel.

\section{Results}

We identified 350 records overall. According to exclusion criteria i, ii and iii, 147 records were removed after Title/Abstract screening. Finally, we screened 203 records. From these records we extrapolated 944 cases of interest assessed for eligibility. One case, after duplicate, was removed, and 36 cases were excluded according to exclusion criteria i (out of scope) and iv (insufficient available data). In the present review we only analyzed cases regarding SOT recipients published from 1996 to 2016 and available on the PubMed database with sufficient data for inclusion on synthesis of results (n 907) [4-203]. Previously, allogeneic HSCT and parasitic infections were reviewed and discussed [204].

We summarized all literature reports on parasitosis after SOT on the basis of the parasite involved (non-intestinal protozoa, intestinal protozoa, intestinal helminths, and non-intestinal helminths) (Figure 3), grouping by: (i) type of transplanted organ (Table 1); (ii) country of origin or nationality, and reported risk factors (e.g., immigration/travel history) for both donor and recipient of SOT (Table 2); (iii) manner of parasitic acquisition (donor-derived through graft or transfusions, and primary infection by means of natural infection) and reactivation (Table 3); (iv) parasitic disease onset from transplantation (early 0-29 days, middle 30-100 days, and late $>100$ days) (Table 4); (v) laboratory diagnostic methods (direct and indirect methods performed in the ante- and/or post-mortem period) (Table 5); (vi) parasitic disease treatment (Table 6); (vii) patient outcome (Table 6). 
Table 1. Post-SOT parasitosis grouped by transplanted organ

\begin{tabular}{|c|c|c|c|c|c|c|c|c|c|c|c|}
\hline \multirow[b]{2}{*}{ Infectious Agent } & \multirow{2}{*}{$\begin{array}{l}\text { Post-SOT Parasitosis } \\
\text { (Total Number of } \\
\text { Reported Cases) }\end{array}$} & \multicolumn{10}{|c|}{ Post-SOT Parasitosis by Transplantation Type, n (\%) } \\
\hline & & Kidney & Liver & Heart & Lung & Pancreas & Bowel & $\begin{array}{l}\text { Iliac } \\
\text { Vassel }\end{array}$ & Cornea & Multi-organ & $\begin{array}{c}\text { Not } \\
\text { Specified }\end{array}$ \\
\hline \multicolumn{12}{|c|}{ Non-intestinal protozoan parasitic infection in SOT (n 465) } \\
\hline Toxoplasma gondii & 162 & $75(46.3 \%)$ & $19(11.7 \%)$ & $55(34 \%)$ & $1(0.6 \%)$ & $1(0.6 \%)$ & $1(0.6 \%)$ & & & $6(3.7 \%)$ & $4(2.5 \%)$ \\
\hline Leishmania spp. & 151 & $127(84.1 \%)$ & $13(8.6 \%)$ & $8(5.3 \%)$ & $3(2 \%)$ & & & & & & \\
\hline Trypanosoma cruzi & 88 & $20(22.7 \%)$ & $11(12.5 \%)$ & $53(60.2 \%)$ & $2(2.3 \%)$ & & & & & $2(2.3 \%)$ & \\
\hline Plasmodium spp. & 27 & $16(59.3 \%)$ & $5(18.5 \%)$ & $2(7.4 \%)$ & & & & & & & $4(14.8 \%)$ \\
\hline Babesia & 5 & $4(80 \%)$ & & $1(20 \%)$ & & & & & & & \\
\hline Acanthamoeba spp. & 17 & $13(76.4 \%)$ & $1(5.9 \%)$ & & $1(5.9 \%)$ & & $1(5.9 \%)$ & & & $1(5.9 \%)$ & $1(5.9 \%)$ \\
\hline Balamuthia mandrillaris & 9 & $4(44.5 \%)$ & $2(22.2 \%)$ & $1(11.1 \%)$ & & & & $1(11.1 \%)$ & & $1(11.1 \%)$ & \\
\hline Lophomonas biattarum & 6 & $6(100 \%)$ & & & & & & & & & \\
\hline \multicolumn{12}{|c|}{ Intestinal protozoan parasitic infection in SOT (n 350) } \\
\hline Cryptosporidium spp. & 210 & $177(84.3 \%)$ & $11(5.2 \%)$ & $1(0.5 \%)$ & $1(0.5 \%)$ & & $7(3.3 \%)$ & & & & $13(6.2 \%)$ \\
\hline Blastocystis spp. & 32 & $31(96.9 \%)$ & & & & & & & & & $1(3.1 \%)$ \\
\hline Giardia spp. & 18 & $8(44.4 \%)$ & & & & & & & & $1(5.6 \%)$ & $9(50 \%)$ \\
\hline Entamoeba histolytica & 2 & & $1(50 \%)$ & & & & & & & & $1(50 \%)$ \\
\hline Entamoebae spp. & 10 & $10(100 \%)$ & & & & & & & & & \\
\hline Chilomastix mesnili & 1 & $1(100 \%)$ & & & & & & & & & \\
\hline Microsporidia spp. & 77 & $50(64.9 \%)$ & $10(13 \%)$ & $1(1.3 \%)$ & $1(1.3 \%)$ & & & & $1(1.3 \%)$ & $3(3.9 \%)$ & $11(14.3 \%)$ \\
\hline \multicolumn{12}{|c|}{ Intestinal helminthic parasitic infection in SOT (n 78) } \\
\hline Strongyioides stercoralis & 72 & $38(52.8 \%)$ & $6(8.3 \%)$ & $5(6.9 \%)$ & $2(2.8 \%)$ & $1(1.4 \%)$ & $2(2.8 \%)$ & & & $5(6.9 \%)$ & $13(18.1 \%)$ \\
\hline Taenia soliun & 2 & & $2(100 \%)$ & & & & & & & & \\
\hline Trichuris trichiura & 1 & $1(100 \%)$ & & & & & & & & & \\
\hline Ascaris lumbricoides & 2 & $2(100 \%)$ & & & & & & & & & \\
\hline Dipylidium caninum & 1 & $1(100 \%)$ & & & & & & & & & \\
\hline \multicolumn{12}{|c|}{ Non-intestinal helminthic parasitic infection in SOT (n 14) } \\
\hline Schistosoma spp. & 6 & & $6(100 \%)$ & & & & & & & & \\
\hline Echinococcus granulosus & 2 & $2(100 \%)$ & & & & & & & & & \\
\hline $\begin{array}{l}\text { Echinococcus } \\
\text { multilocularis }\end{array}$ & 6 & $1(16.7 \%)$ & & 5 (83.3\%) & & & & & & & \\
\hline
\end{tabular}


Table 2. Post-SOT parasitosis grouped by donor and recipient characteristics.

\begin{tabular}{|c|c|c|c|c|c|c|c|c|c|c|c|c|c|}
\hline \multirow{3}{*}{ Infectious Agent } & \multirow{3}{*}{$\begin{array}{l}\text { Post-SOT Parasitosis } \\
\text { (Total Number of } \\
\text { Reported Cases) }\end{array}$} & \multicolumn{12}{|c|}{ Country of Origin or Nationality and/or Reported Risk Factors (e.g., Immigration/Travel History), n (\%) } \\
\hline & & \multicolumn{6}{|c|}{ Donor } & \multicolumn{6}{|c|}{ Recipent } \\
\hline & & $\begin{array}{l}\text { North } \\
\text { America }\end{array}$ & $\begin{array}{l}\text { South/Central } \\
\text { America }\end{array}$ & Africa & Asia & EU/EAA & n.a. & $\begin{array}{c}\text { North } \\
\text { America }\end{array}$ & $\begin{array}{l}\text { South/Central } \\
\text { America }\end{array}$ & Africa & Asia & EU/EAA & n.a. \\
\hline \multicolumn{14}{|c|}{ Non-intestinal protozoan parasitic infection in SOT (n 465) } \\
\hline Toxoplasma gondii & 162 & & & & & $1(0.6 \%)$ & $\begin{array}{c}161 \\
(99.4 \%)\end{array}$ & & & & $1(0.6 \%)$ & & $\begin{array}{c}161 \\
(99.4 \%)\end{array}$ \\
\hline Leishmania spp. & 151 & & & & & & $\begin{array}{c}151 \\
(100 \%)\end{array}$ & & & & & & $\begin{array}{c}151 \\
(100 \%)\end{array}$ \\
\hline Trypanosoma cruzi & 88 & $5(5.7 \%)$ & $17(19.3 \%)$ & & & & $66(75 \%)$ & $3(3.4 \%)$ & $5(5.7 \%)$ & & & $1(1.1 \%)$ & $\begin{array}{c}79 \\
(89.8 \%)\end{array}$ \\
\hline Plasmodium spp. & 27 & & & $5(18.5)$ & $3(11.1 \%)$ & & $\begin{array}{c}19 \\
(70.4 \%)\end{array}$ & & & & $2(7.4 \%)$ & & $\begin{array}{c}25 \\
(92.6 \%)\end{array}$ \\
\hline Babesia & 5 & $3(60 \%)$ & & & & & $2(40 \%)$ & $3(60 \%)$ & & & & & $2(40 \%)$ \\
\hline Acanthamoeba spp. & 17 & & & & & & $\begin{array}{c}17 \\
(100 \%)\end{array}$ & $2(11.8 \%)$ & & & & & $\begin{array}{c}15 \\
(88.2 \%)\end{array}$ \\
\hline $\begin{array}{l}\text { Balamuthia } \\
\text { mandrillaris }\end{array}$ & 9 & $4(44.4 \%)$ & & & & & $5(55.6 \%)$ & & & & & & $9(100 \%)$ \\
\hline Lophomonas biattarum & 6 & & & & & & $6(100 \%)$ & & & & $2(33.3 \%)$ & & $4(66.7 \%)$ \\
\hline \multicolumn{14}{|c|}{ Intestinal protozoan parasitic infection in SOT (n 350) } \\
\hline Cryptosporidium spp. & 210 & & & & & & $\begin{array}{c}210 \\
(100 \%)\end{array}$ & & & & & & $\begin{array}{c}210 \\
(100 \%)\end{array}$ \\
\hline Blastocystis spp. & 32 & & & & & & $\begin{array}{c}32 \\
(100 \%)\end{array}$ & & & & & & $\begin{array}{c}32 \\
(100 \%)\end{array}$ \\
\hline Giardia spp. & 18 & & & & & & $\begin{array}{c}18 \\
(100 \%)\end{array}$ & & & & & & $\begin{array}{c}18 \\
(100 \%)\end{array}$ \\
\hline Entamoeba histolytica & 2 & & & & & & $2(100 \%)$ & & & & & & $2(100 \%)$ \\
\hline Entamoebae spp. & 10 & & & & & & $\begin{array}{c}10 \\
(100 \%)\end{array}$ & & & & & & $\begin{array}{c}10 \\
(100 \%)\end{array}$ \\
\hline Chilomastix mesnili & 1 & & & & & & $1(100 \%)$ & & & & & & $1(100 \%)$ \\
\hline Microsporidia spp. & 77 & & & & & $1(1.3 \%)$ & $\begin{array}{c}76 \\
(98.7 \%) \\
\end{array}$ & & & & & & $\begin{array}{c}77 \\
(100 \%)\end{array}$ \\
\hline \multicolumn{14}{|c|}{ Intestinal helminthic parasitic infection in SOT (n 78) } \\
\hline $\begin{array}{l}\text { Strongyioides } \\
\text { stercoralis }\end{array}$ & 72 & $3(4.2 \%)$ & $28(38.9 \%)$ & & $9(12.5 \%)$ & & $\begin{array}{c}32 \\
(44.4 \%) \\
\end{array}$ & $7(9.7 \%)$ & $15(20.8 \%)$ & $1(1.4 \%)$ & $9(12.5 \%)$ & $3(4.2 \%)$ & $\begin{array}{c}37 \\
(51.4 \%) \\
\end{array}$ \\
\hline Taenia soliun & 2 & & & & & & $2(100 \%)$ & & $1(50 \%)$ & & & & \\
\hline Trichuris trichiura & 1 & & & & & & $1(100 \%)$ & & & & & & $1(100 \%)$ \\
\hline Ascaris lumbricoides & 2 & & & & & & $2(100 \%)$ & & & & & & $2(100 \%)$ \\
\hline Dipylidium caninum & 1 & & & & & & $1(100 \%)$ & & & & & & $1(100 \%)$ \\
\hline
\end{tabular}


Table 2. Cont.

\begin{tabular}{|c|c|c|c|c|c|c|c|c|c|c|c|c|c|}
\hline \multirow{3}{*}{ Infectious Agent } & \multirow{3}{*}{$\begin{array}{l}\text { Post-SOT Parasitosis } \\
\text { (Total Number of } \\
\text { Reported Cases) }\end{array}$} & \multicolumn{12}{|c|}{ Country of Origin or Nationality and/or Reported Risk Factors (e.g., Immigration/Travel History), n (\%) } \\
\hline & & \multicolumn{6}{|c|}{ Donor } & \multicolumn{6}{|c|}{ Recipent } \\
\hline & & $\begin{array}{l}\text { North } \\
\text { America }\end{array}$ & $\begin{array}{l}\text { South/Central } \\
\text { America }\end{array}$ & Africa & Asia & EU/EAA & n.a. & $\begin{array}{c}\text { North } \\
\text { America }\end{array}$ & $\begin{array}{l}\text { South/Central } \\
\text { America }\end{array}$ & Africa & Asia & EU/EAA & n.a. \\
\hline \multicolumn{14}{|c|}{ Non-intestinal helminthic parasitic infection in SOT (n 14) } \\
\hline Schistosoma spp. & 6 & & & & & & $6(100 \%)$ & & & $2(33.3 \%)$ & & & $4(66.7 \%)$ \\
\hline $\begin{array}{l}\text { Echinococcus } \\
\text { granulosus }\end{array}$ & 2 & & & & & & $2(100 \%)$ & & & & $1(50 \%)$ & & $1(50 \%)$ \\
\hline $\begin{array}{l}\text { Echinococcus } \\
\text { multilocularis }\end{array}$ & 6 & & & & & & $6(100 \%)$ & & & & & & $6(100 \%)$ \\
\hline
\end{tabular}

Table 3. Post-SOT parasitosis grouped by parasitic acquisition way.

\begin{tabular}{|c|c|c|c|c|c|c|}
\hline \multirow{2}{*}{ Infectious Agent } & \multirow{2}{*}{$\begin{array}{l}\text { Post-SOT Parasitosis (Total } \\
\text { Number of Reported Cases) }\end{array}$} & \multicolumn{3}{|c|}{ Acquisition Mode, n (\%) } & \multirow{2}{*}{ Reactivation, $\mathrm{n}(\%)$} & \multirow{2}{*}{ Not Available, n (\%) } \\
\hline & & Natural & Graft & Transfusion & & \\
\hline \multicolumn{7}{|c|}{ Non-intestinal protozoan parasitic infection in SOT (n 465) } \\
\hline Toxoplasma gondii & 162 & $16(9.9 \%)$ & $51(31.5 \%)$ & & $13(8 \%)$ & $82(50.6 \%)$ \\
\hline Leishmania spp. & 151 & $1(0.7 \%)$ & & & $5(3.3 \%)$ & $145(96 \%)$ \\
\hline Trypanosoma cruzi & 88 & $2(2.3 \%)$ & $29(32.9 \%)$ & & $49(55.7 \%)$ & $8(9.1 \%)$ \\
\hline Plasmodium spp. & 27 & $1(3.7 \%)$ & $11(40.7 \%)$ & $1(3.7 \%)$ & & $14(51.8 \%)$ \\
\hline Babesia & 5 & & $2(40 \%)$ & $2(40 \%)$ & & $1(20 \%)$ \\
\hline Acanthamoeba spp. & 17 & & & & & $17(100 \%)$ \\
\hline Balamuthia mandrillaris & 9 & & $9(100 \%)$ & & & \\
\hline Lophomonas biattarum & 6 & $2(33.3 \%)$ & & & & $4(66.7 \%)$ \\
\hline \multicolumn{7}{|c|}{ Intestinal protozoan parasitic infection in SOT (n 350) } \\
\hline Cryptosporidium spp. & 210 & & & & $7(3.3 \%)$ & $203(96.7 \%)$ \\
\hline Blastocystis spp. & 32 & & & & & $32(100 \%)$ \\
\hline Giardia spp. & 18 & & $1(5.6 \%)$ & & & $17(94.4 \%)$ \\
\hline Entamoeba histolytica & 2 & & & & & $2(100 \%)$ \\
\hline Entamoebae spp. & 10 & & & & & $10(100 \%)$ \\
\hline
\end{tabular}


Table 3. Cont

\begin{tabular}{|c|c|c|c|c|c|c|}
\hline \multirow{2}{*}{ Infectious Agent } & \multirow{2}{*}{$\begin{array}{l}\text { Post-SOT Parasitosis (Total } \\
\text { Number of Reported Cases) }\end{array}$} & \multicolumn{3}{|c|}{ Acquisition Mode, $\mathrm{n}(\%)$} & \multirow{2}{*}{ Reactivation, n (\%) } & \multirow{2}{*}{ Not Available, n (\%) } \\
\hline & & Natural & Graft & Transfusion & & \\
\hline Chilomastix mesnili & 1 & & & & & $1(100 \%)$ \\
\hline Microsporidia spp. & 77 & & & & & $77(100 \%)$ \\
\hline \multicolumn{7}{|c|}{ Intestinal helminthic parasitic infection in SOT (n 78) } \\
\hline Strongyioides stercoralis & 72 & & $37(51.4 \%)$ & & $2(2.8 \%)$ & $33(45.8 \%)$ \\
\hline Taenia soliun & 2 & & & & $1(50 \%)$ & $1(50 \%)$ \\
\hline Trichuris trichiura & 1 & & & & & $1(100 \%)$ \\
\hline Ascaris lumbricoides & 2 & & & & & $2(100 \%)$ \\
\hline Dipylidium caninum & 1 & & & & & $1(100 \%)$ \\
\hline \multicolumn{7}{|c|}{ Non-intestinal helminthic parasitic infection in SOT (n 14) } \\
\hline Schistosoma spp. & 6 & & $4(66.7 \%)$ & & $2(33.3 \%)$ & \\
\hline Echinococcus granulosus & 2 & & & & $1(50 \%)$ & $1(50 \%)$ \\
\hline Echinococcus multilocularis & 6 & & & \multicolumn{2}{|c|}{$5(83.3 \%)$} & $1(16.7 \%)$ \\
\hline
\end{tabular}

Table 4. Post-SOT parasitosis grouped by parasitic disease onset from transplantation.

\begin{tabular}{|c|c|c|c|c|c|}
\hline \multirow{2}{*}{ Infectious Agent } & \multirow{2}{*}{$\begin{array}{c}\text { Post-SOT (Total Number of } \\
\text { Reported Cases) }\end{array}$} & \multicolumn{4}{|c|}{ Parasitic Disease Onset, n (\%) } \\
\hline & & 0-29 d PT & 30-100 d PT & $>100 \mathrm{~d}$ PT & n.a. \\
\hline \multicolumn{6}{|c|}{ Non-intestinal protozoan parasitic infection in SOT (n 465) } \\
\hline Toxoplasma gondii & 162 & $7(4.3 \%)$ & $60(37.1 \%)$ & $14(8.6 \%)$ & $81(50 \%)$ \\
\hline Leishimania spp. & 151 & & & $23(15.2 \%)$ & $128(84.8 \%)$ \\
\hline Trypanosoma cruzi & 88 & $1(1.1 \%)$ & $23(26.1 \%)$ & $6(6.8 \%)$ & $58(66 \%)$ \\
\hline Plasmodium spp. & 27 & $3(11.2 \%)$ & $13(48.1 \%)$ & & $11(40.7 \%)$ \\
\hline Babesia & 5 & & $3(60 \%)$ & & $2(40 \%)$ \\
\hline Acanthamoeba spp. & 17 & & & $3(17.6 \%)$ & $14(82.4 \%)$ \\
\hline Balamuthia mandrillaris & 9 & $3(33.3 \%)$ & & & $6(66.7 \%)$ \\
\hline Lophomonas biattarum & 6 & & $4(66.7 \%)$ & $2(33.3 \%)$ & \\
\hline
\end{tabular}


Table 4. Cont

\begin{tabular}{|c|c|c|c|c|c|}
\hline \multirow{2}{*}{ Infectious Agent } & \multirow{2}{*}{$\begin{array}{c}\text { Post-SOT (Total Number of } \\
\text { Reported Cases) }\end{array}$} & \multicolumn{4}{|c|}{ Parasitic Disease Onset, n (\%) } \\
\hline & & 0-29 d PT & $30-100 \mathrm{~d}$ PT & $>100 \mathrm{~d}$ PT & n.a. \\
\hline \multicolumn{6}{|c|}{ Intestinal protozoan parasitic infection in SOT (n 350) } \\
\hline Cryptosporidium spp. & 210 & $1(0.5 \%)$ & & $64(30.5 \%)$ & $145(69 \%)$ \\
\hline Blastocystis spp. & 32 & & & & $32(100 \%)$ \\
\hline Giardia spp. & 18 & & & & $18(100 \%)$ \\
\hline Entamoeba histolytica & 2 & & & & $2(100 \%)$ \\
\hline Entamoebae spp. & 10 & & & & $10(100 \%)$ \\
\hline Chilomastix mesnili & 1 & & & & $1(100 \%)$ \\
\hline Microsporidia spp. & 77 & & 4 & 24 & 49 \\
\hline \multicolumn{6}{|c|}{ Intestinal helminthic parasitic infection in SOT (n 78) } \\
\hline Strongyioides stercoralis & 72 & $4(5.5 \%)$ & $20(27.8 \%)$ & $9(12.5 \%)$ & $39(54.2 \%)$ \\
\hline Taenia soliun & 2 & & $1(50 \%)$ & $1(50 \%)$ & \\
\hline Trichuris trichiura & 1 & & & & $1(100 \%)$ \\
\hline Ascaris lumbricoides & 2 & & & & $2(100 \%)$ \\
\hline Dipylidium caninum & 1 & & & $1(100 \%)$ & \\
\hline \multicolumn{6}{|c|}{ Non-intestinal helminthic parasitic infection in SOT (n 14) } \\
\hline Schistosoma spp. & 6 & & $1(16.7 \%)$ & & $5(83.3 \%)$ \\
\hline Echinococcus granulosus & 2 & & & $2(100 \%)$ & \\
\hline $\begin{array}{l}\text { Echinococcus } \\
\text { multilocularis }\end{array}$ & 6 & & & $5(83.3 \%)$ & $1(16.7 \%)$ \\
\hline
\end{tabular}


Table 5. Post-SOT parasitosis grouped by laboratory diagnostic methods.

\begin{tabular}{|c|c|c|c|c|c|c|c|}
\hline \multirow{3}{*}{ Infectious Agent } & \multirow{3}{*}{$\begin{array}{l}\text { Post-SOT Parasitosis (Total } \\
\text { Number of Reported Cases) }\end{array}$} & \multicolumn{6}{|c|}{ Laboratories Diagnosis in Transplant Recipient, $\mathrm{n}(\%)$} \\
\hline & & \multicolumn{3}{|c|}{ Direct } & \multirow{2}{*}{ Indirect } & \multirow{2}{*}{$\begin{array}{c}\text { Both } \\
\text { (Direct/Indirect) }\end{array}$} & \multirow{2}{*}{ n.a. } \\
\hline & & Ante-Mortem & Post-Mortem & Both (ante/post) & & & \\
\hline \multicolumn{8}{|c|}{ Non-intestinal protozoan parasitic infection in SOT (n 465) } \\
\hline Toxoplasma gondii & 162 & $11(6.8 \%)$ & $2(1.2 \%)$ & & $18(11.1 \%)$ & $5(3.1 \%)$ & $126(77.8 \%)$ \\
\hline Leishmania spp. & 151 & $32(21.2 \%)$ & $1(0.7 \%)$ & & $3(1.9 \%)$ & $48(31.8 \%)$ & $67(44.4 \%)$ \\
\hline Trypanosoma cruzi & 88 & $24(27.3 \%)$ & $1(1.1 \%)$ & & $5(5.7 \%)$ & $12(13.6 \%)$ & $46(52.3 \%)$ \\
\hline Plasmodium spp. & 27 & $22(81.5 \%)$ & & & $1(3.7 \%)$ & $1(3.7 \%)$ & $3(11.1 \%)$ \\
\hline Babesia & 5 & & & & & $3(60 \%)$ & $2(40 \%)$ \\
\hline Acanthamoeba spp. & 17 & $2(11.8 \%)$ & $2(11.8 \%)$ & & & & $13(76.4 \%)$ \\
\hline Balamuthia mandrillaris & 9 & $1(11.1 \%)$ & $2(22.2 \%)$ & $2(22.2 \%)$ & & $4(44.5 \%)$ & \\
\hline Lophomonas biattarum & 6 & $6(100 \%)$ & & & & & \\
\hline \multicolumn{8}{|c|}{ Intestinal protozoan parasitic infection in SOT (n 350) } \\
\hline Cryptosporidium spp. & 210 & $143(68.1 \%)$ & & & $2(0.9 \%)$ & $17(8.1 \%)$ & $48(22.9 \%)$ \\
\hline Blastocystis spp. & 32 & $29(90.6 \%)$ & & & & & $3(9.4 \%)$ \\
\hline Giardia spp. & 18 & & & & & & $18(100 \%)$ \\
\hline Entamoeba histolytica & 2 & & & & & & $2(100 \%)$ \\
\hline Entamoebae spp. & 10 & & & & & & $10(100 \%)$ \\
\hline Chilomastix mesnili & 1 & & & & & & $1(100 \%)$ \\
\hline Microsporidia spp. & 77 & $70(90.9 \%)$ & $2(2.6 \%)$ & & & $4(5.2 \%)$ & $1(1.3 \%)$ \\
\hline \multicolumn{8}{|c|}{ Intestinal helminthic parasitic infection in SOT (n 78) } \\
\hline Strongyioides stercoralis & 72 & $21(29.1 \%)$ & $1(1.4 \%)$ & $1(1.4 \%)$ & $1(1.4 \%)$ & & $48(66.7 \%)$ \\
\hline Taenia soliun & 2 & $1(50 \%)$ & & & $1(50 \%)$ & & \\
\hline Trichuris trichiura & 1 & $1(100 \%)$ & & & & & \\
\hline Ascaris lumbricoides & 2 & $2(100 \%)$ & & & & & \\
\hline Dipylidium caninum & 1 & $1(100 \%)$ & & & & & \\
\hline \multicolumn{8}{|c|}{ Non-intestinal helminthic parasitic infection in SOT (n 14) } \\
\hline Schistosoma spp. & 6 & $6(100 \%)$ & & & & & \\
\hline Echinococcus granulosus & 2 & $1(50 \%)$ & & & & & $1(50 \%)$ \\
\hline Echinococcus multilocularis & 6 & & & & $1(16.7 \%)$ & $5(83.3 \%)$ & \\
\hline
\end{tabular}


Table 6. Post-SOT parasitosis grouped by parasitic disease treatment and patient outcome *

\begin{tabular}{|c|c|c|c|c|c|c|c|c|c|}
\hline \multirow[b]{2}{*}{ Infectious Agent } & \multirow[b]{2}{*}{$\begin{array}{l}\text { Post-SOT Parasitosis (Total } \\
\text { Number of Reported Cases) }\end{array}$} & \multicolumn{4}{|c|}{ Parasitic Disease Treatment, n (\%) } & \multicolumn{4}{|c|}{ Outcome, m (\%) } \\
\hline & & $\begin{array}{l}\text { Standard } \\
\text { Treatment }\end{array}$ & $\begin{array}{l}\text { Alternative } \\
\text { Regimen }\end{array}$ & Not Done & n.a & Recovery & Death & Replace & n. a \\
\hline \multicolumn{10}{|c|}{ Non-Intestinal protozoan parasitic infections in SOT (n 465) } \\
\hline Toxoplasma gondii & 162 & $76(46.9 \%)$ & & & $86(53.1 \%)$ & $50(30.9 \%)$ & $22(13.6 \%)$ & $1(0.6 \%)$ & $89(54.9 \%)$ \\
\hline Leishmania spp. & 151 & $60(39.7 \%)$ & & & $91(60.3 \%)$ & $34(22.5 \%)$ & $8(8.3 \%)$ & $58(38.4 \%)$ & $51(33.8 \%)$ \\
\hline Trypanosoma cruzi & 88 & $33(37.5 \%)$ & & $4(4.5 \%)$ & $51(58 \%)$ & $16(18.2 \%)$ & $20(22.7 \%)$ & $2(2.3 \%)$ & $50(56.8 \%)$ \\
\hline Plasmodium spp. & 27 & $17(63 \%)$ & & & $10(37 \%)$ & $20(74.1 \%)$ & $1(3.7 \%)$ & & $6(22.2 \%)$ \\
\hline Babesia & 5 & $4(80 \%)$ & & & $1(20 \%)$ & $3(60 \%)$ & & & $2(40 \%)$ \\
\hline Acanthamoeba spp. & 17 & & & & $17(100 \%)$ & $5(29.4 \%)$ & $11(67.4 \%)$ & & $1(5.9 \%)$ \\
\hline Balamuthia mandrillaris & 9 & $6(66.7 \%)$ & & $1(11.1 \%)$ & $2(22.2 \%)$ & $5(55.6 \%)$ & $4(44.4 \%)$ & & \\
\hline Lophomonas biattarum & 6 & $2(33.3 \%)$ & & & $4(66.7 \%)$ & $2(33.3 \%)$ & & & $4(66.7 \%)$ \\
\hline \multicolumn{10}{|c|}{ Intestinal protozoan parasitic infections in SOT (n 350) } \\
\hline Cryptosporidium spp. & 210 & $185(88.1 \%)$ & $1(0.5 \%)$ & & $24(11.4 \%)$ & $176(83.8 \%)$ & $3(1.4 \%)$ & $7(3.4 \%)$ & $24(11.4 \%)$ \\
\hline Blastocystis spp. & 32 & $2(6.2 \%)$ & & & $30(93.8 \%)$ & & & & $32(100 \%)$ \\
\hline Giardia spp. & 18 & & & & $18(100 \%)$ & $1(5.6 \%)$ & & & $17(94.4 \%)$ \\
\hline Entamoeba histolytica & 2 & $1(50 \%)$ & & & $1(50 \%)$ & $1(50 \%)$ & & & $1(50 \%)$ \\
\hline Entamoebae spp. & 10 & & & & $10(100 \%)$ & & & & $10(100 \%)$ \\
\hline Chilomastix mesnili & 1 & & & & $1(100 \%)$ & & & & $1(100 \%)$ \\
\hline Microsporidia spp. & 77 & $52(67.5 \%)$ & $1(1.3 \%)$ & $4(5.2 \%)$ & $20(26 \%)$ & $28(36.4 \%)$ & $4(5.2 \%)$ & $2(2.6 \%)$ & $43(55.8 \%)$ \\
\hline \multicolumn{10}{|c|}{ Intestinal protozoan parasitic infections in SOT (n 78) } \\
\hline Strongyioides stercoralis & 72 & $34(45.8 \%)$ & & & $39(54.2 \%)$ & $37(51.4 \%)$ & $23(31.9 \%)$ & $2(2.8 \%)$ & $10(13.9 \%)$ \\
\hline Taenia soliun & 2 & $1(50 \%)$ & $1(50 \%)$ & & & $2(100 \%)$ & & & \\
\hline Trichuris trichiura & 1 & $1(100 \%)$ & & & & $1(100 \%)$ & & & \\
\hline Ascaris lumbricoides & 2 & & & & $2(100 \%)$ & & & & $2(100 \%)$ \\
\hline Dipylidium caninum & 1 & $1(100 \%)$ & & & & $1(100 \%)$ & & & \\
\hline \multicolumn{10}{|c|}{ Non-Intestinal protozoan parasitic infections in SOT (n 14) } \\
\hline Schistosoma spp. & 6 & $2(33.3 \%)$ & & $4(66.7 \%)$ & & $4(66.7 \%)$ & $2(33.3 \%)$ & & \\
\hline Echinococcus granulosus & 2 & $2(100 \%)$ & & & & $2(100 \%)$ & & & \\
\hline Echinococcus multilocularis & 6 & $2(88.3 \%)$ & & & $1(16.7 \%)$ & $3(50 \%)$ & $2(33.3 \%)$ & & $1(16.7 \%)$ \\
\hline
\end{tabular}

Echinococcus multilocularis $\quad 6$

* Out of all reported cases with specified standard or alternative treatment regimens, around $76 \%$ had favorable outcome with recovery, about $12 \%$ had negative outcome with death, whereas about $6 \%$ experienced recurrence, with the remaining having unspecified outcome. 


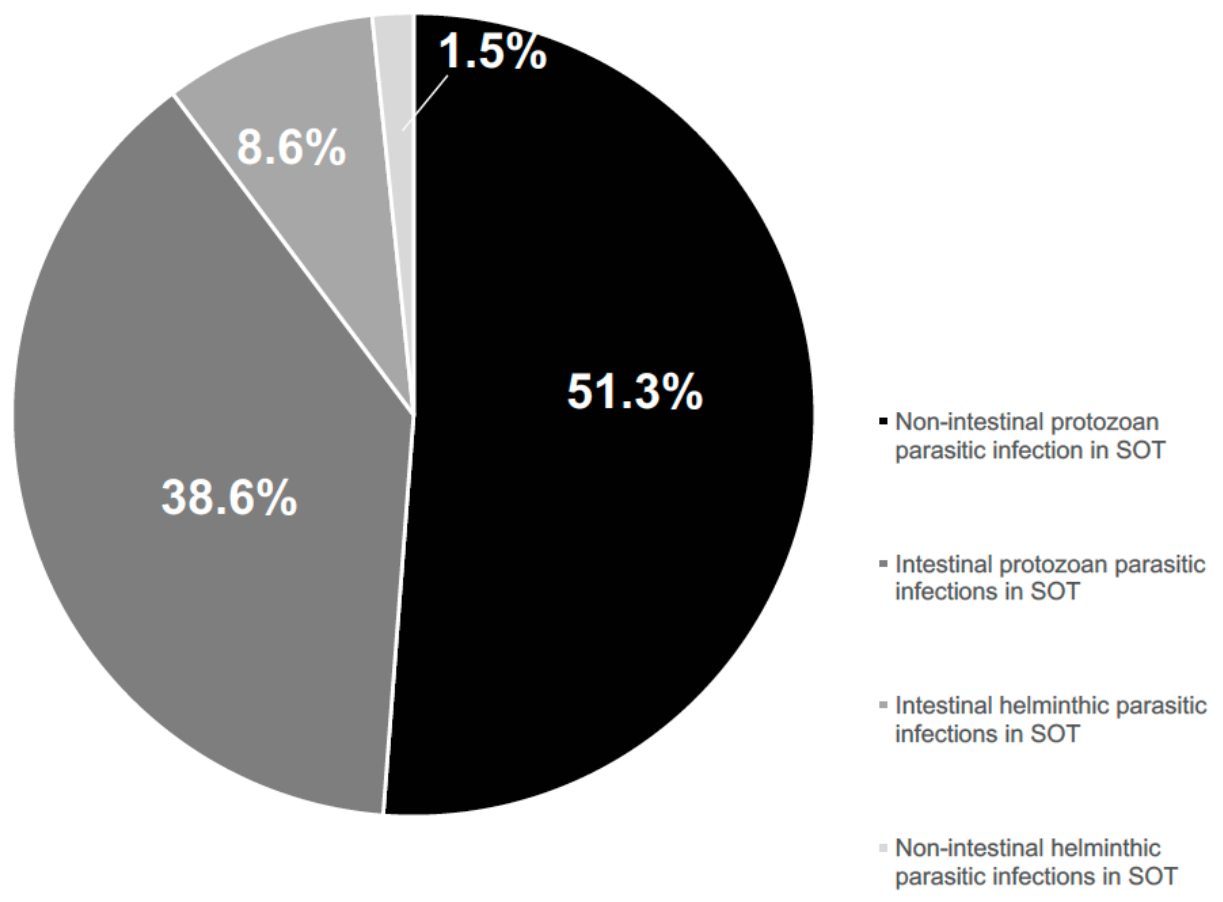

Figure 3. Parasitosis reported cases among SOT recipients by infectious agent (protozoa or helminths) (PubMed published data per period 1996-2016).

\section{Discussion}

According to published literature and available data, parasitic infections represent a possible complication after SOT. Studies on this topic are evolving fields that are receiving increased recognition.

Transplant recipients may develop parasitic disease after acquisition of the parasite at the time of transplantation, either with the allograft or with blood and blood products, as well as in the post-transplantation period, through the traditional route of infection, or, as a consequence of immunosuppression, due to the reactivation of a dormant infection [2]. Indeed, many difficulties can often take place in the identification of the manner of acquisition of parasitic infections.

When parasitic infections occur in immunosuppressed people, they can manifest with several features. Clinical severity and outcome certainly depend on parasite features, innate and acquired host immunity as well as on immune interaction between parasite and host.

Blood parasites (e.g., Plasmodium spp., Babesia, Schistosoma spp.), tissue parasites (e.g., Leishmania spp, Toxoplasma gondii, Trypanosoma cruzi, Acanthamoeba), and intestinal parasites (e.g., Microsporidia spp., Cryptosporidium spp., Entamoeba spp., Giardia duodenalis, Strongyloides stercoralis, Taenia solium, Trichuris trichiura, Ascaris lumbricoides) can induce both localized syndrome and systemic illness. Due to the immunocompromised status of the host, the localized syndromes evolve into acute systemic illness more often than in the general population.

Prolonged fever alone or in combination with other systemic manifestations, anemia, lower gastrointestinal symptoms, and variable stigmata of organ involvement represent the most frequent clinical pattern, occurring in many parasitosis. Actually, it is difficult to identify and interpret all potential clinical patterns in which non-infectious events such as conditioning regimens, drugs, and acute GVHD may interfere.

Means of acquisition, clinical features, diagnostic methods and treatment measures of the most serious parasitic-specific infections reported in SOT recipients are listed below. 


\subsection{Non-Intestinal Protozoan Infections}

Toxoplasmosis is a life-threatening opportunistic infection that may affect transplanted people. It is caused by the coccidian Toxoplasma gondii. Its occurrence in these patients is closely related to the prevalence of toxoplasmosis in the general population, which is high in Europe, but declining in recent decades $[205,206]$.

In published and available reviewed literature, we found 162 case reports of toxoplasmosis occurring after SOT [4-27]. Of interest, in SOT recipients, toxoplasmosis results more frequently from transmission of the parasite with the transplanted organ from a Toxoplasma-seropositive donor (D+) to a Toxoplasma-seronegative recipient $(\mathrm{R}-)$. This risk is greater for transplantation of organs with high numbers of tissue cysts, e.g., the heart (see muscles sustaining parasite encystment), and it is markedly lower for the other organs [207]. Transmission of T. gondii from a D+ to an R+ may also occur. In this case, graft transmission is difficult to confirm and to differentiate from a reactivation of latent infection in the recipient. However, the hypothesis of reinfection of an $\mathrm{R}+$ from a $\mathrm{D}+$ has been suggested by Robert-Gangneux et al. [207]. In this study, western blot (WB) analysis of post-transplant sera of R+ showed neosynthesized IgG, probably related to the recognition of the new parasite strain acquired via the transplanted organ from a D+. This reinfection could be proved only with the identification of the infecting strain(s), by serotyping or genotyping [208-210].

In case of a recently infected donor, the possible presence of $T$. gondii in the blood represents a potential risk of transmission to an $\mathrm{R}-$.

According to the literature data on post-transplant toxoplasmosis, transmission occurred through graft in 31.5\% (n 51), de novo infection in 9.9\% (n 16) and reactivation in 8\% (n 13). However, in 50.6\% (n 82) the modality of infection remained unknown.

As already said, although heart transplant is riskier for organ-related toxoplasmosis than liver, lung, or kidney transplant, data from the last decade published records showed kidney transplant as the most frequently implicated in post-transplant toxoplasmosis ( $\mathrm{n} 75,46.3 \%$ ), followed by heart (n 55, 34\%). Liver (n 19, 11.7\%), bowel, pancreas, lung and simultaneous multivisceral (few cases) transplants have also been reported.

Toxoplasmosis in the immunocompromised host presents with pyrexia, lymphadenopathy, and multiorgan involvement. Anemia is common, and a hemophagocytic syndrome has been reported in several cases [211]. Encephalitis, meningoencephalitis, and cerebral mass lesions are serious and frequent complications [9,212]. Chorioretinitis, similar to that observed in Cytomegalovirus (CMV) infection, frequently occurs [25,213]. Myocarditis and pneumonitis are also reported [7,13,214].

According to collected data, primary toxoplasmosis acquired through the graft is usually more severe than reactivation disease (mortality of $31.4 \%$ for graft-related toxoplasmosis versus $7.7 \%$ for reactivation cases) and in the case of graft transmission, it occurs much earlier than reactivation, often within 100 days of transplantation.

The serological status for infection with $T$. gondii in both the donor and recipient must be determined prior to transplantation. After transplantation, the diagnostic work ideally includes not only traditional serological assays but also sensitive techniques like comparative WB between preand post-transplant pattern [207] and polymerase chain reaction (PCR) in biological samples [215]. The study of cellular immune response using toxiferon, useful for the diagnosis of congenital toxoplasmosis [216], is under evaluation in transplanted individuals in few Centres, but to our knowledge no report is present in the literature about the use of such a method in the follow up of transplanted individuals. Moreover, the definitive diagnosis often requires the direct demonstration of parasites (e.g., histologically) or parasitic DNA in blood, bone marrow, cerebrospinal fluid (CSF), bronchoalveolar lavage (BAL) fluid or biopsy specimens. Due to the immunocompromised status of the patients, the serological tests could become less useful for the diagnosis, because of their reduced sensitivity in these conditions.

There is good evidence that in $\mathrm{R}-$ of organs from a $\mathrm{D}+$, prophylaxis with trimethoprimsulfamethoxazole (TMP-SMZ) immediately after transplant reduces the incidence of primary infection: 
particularly in heart transplant, the occurrence decreases from more than $50 \%$ without prophylaxis [217] to about $5 \%$ with prophylaxis [218]. However, fatal disseminated toxoplasmosis has been reported even in the case of seropositivity match, suggesting that prophylaxis should be extended also in these cases [13].

Seronegative candidates must be re-checked immediately before transplant in order to avoid unnecessary chemoprophylaxis, in case of seroconversion. All R- of organs from a D- should follow behavior and dietetic rules to avoid exogenous infection, and should be tested for T. gondii antibodies every six months. R- of organs from a D+ are treated with TMP-SMZ immediately after transplant; moreover, they should follow hygiene and dietetic rules such as those for recipients of organs from a D-.

In these patients, serological tests should be carried out at the end of chemoprophylaxis and then every six months. All patients, including those seropositive before transplant, should be tested for T. gondii serology when presenting with suggestive symptoms. Mild presentations and nonspecific symptoms should raise a suspicion of toxoplasmic disease, particularly after antireject treatment [14]. In cases of strong clinical suspicion, with or without laboratory diagnostic confirmation, full regimen treatment (TMP-SMZ or pyrimethamine-sulphadiazine, as standard treatmet, or clindamycin, clarithromycin, azithromycin or atovaquone, as alternatives) should be recommended [3].

Regarding treatment, some limitations exist because of potential drug to drug interaction between anti-Toxoplasma and immunosuppressive treatments. For example, sulfadiazine or SMX together with cyclosporine (CsA) or tacrolimus (TAC) increases risk of kidney damage, azithromycin together with TAC increases the risk of arrhythmia; sulfadiazine and clindamycin therapy can decrease CsA concentration [3]. On the other hand, the possibility that CsA possesses anti-Toxoplasma activity must be considered [3].

Leishmaniasis is a vector-borne tissue parasitic disease, localized (cutaneous and mucocutaneous) or systemic (visceral leishmaniasis $=\mathrm{VL}$ ), caused by the kinetoplastidae Leishmania genus. Cases are recorded among patients undergoing kidney, liver, heart, lung and pancreas transplantation, with the most significant association with kidney transplantation $(84.1 \%$, based on the 127 cases reported in the literature) [28-60]. VL is the most frequently observed clinical presentation, followed by mucosal and more rarely, cutaneous. Like other parasites, Leishmania spp. can cause asymptomatic infection and then remain dormant in the host for many years, becoming clinically apparent during periods of immunosuppression [219]. As a consequence, leishmaniasis must always be considered in the differential diagnosis of febrile immunosuppressed transplant recipients (especially if renal) with fever, pancytopenia with or without allograft dysfunction [219], especially in endemic areas. The diagnosis in immunosuppressed patients is difficult because of the variability of symptoms and clinical signs, and the poor sensitivity of serology in this setting. Aspiration and biopsy of the bone marrow is the preferred method to confirm infection in such individuals [219]. For kidney transplantation, renal biopsy is also required in the case of graft dysfunction, allowing differential diagnosis between graft rejection, drug-related nephrotoxic lesions and parasitic parenchyma infiltration. The pre-operative check-up with serological testing for leishmaniasis of both transplant patients and donors and the regular post-transplant serological monitoring (although with limitations due to immunosuppressive status) of recipients should be performed to identify people at higher risk of leishmaniasis. Primary prophylaxis is not routinely used, but infection outcome depends on early diagnosis and effective antiparasitic therapy [55]. Treatment choice is conditioned by toxicity and drug interactions, which is even more important in these patients [55]. For this reason, liposomal amphotericin B may be considered the treatment of choice of $\mathrm{VL}$, in consideration of the low incidence of side effects [3].

\subsection{Chagas' Disease}

Chagras' disease is another vector-borne parasitic disease, but caused by the American Trypanosoma, which has a very important impact on public health in Latin America [220]. 
Among the different ways of transmission, that with transplanted organs is reported along with reactivation of dormant infection in transplant recipients. In particular, of 88 SOT recipients described in literature as having trypanosomiasis, $29(32.9 \%)$ had a demonstrated primary infection due to well established transmission through allograft; 49 (55.7\%) had a reactivation, $2(2.3 \%)$ had de novo infection, and 8 (9.1\%) did not have a determined mechanism [15,61-82]).

The most significant association is reported with heart transplantation $(60.2 \%$, based on the 53 cases reported in the literature), with kidney transplantation second (22.7\%, based on the 20 cases reported in the literature).

Indeed, Trypanosoma cruzi itself is responsible for a significant proportion of end-stage cardiomyopathy and heart transplant for Chagas' heart disease should be regarded as a valuable treatment option [221]. Reactivation in Chagasic heart transplant recipients has been reported to occur in between $26.5 \%$ [66] and $42.9 \%$ [221] of patients with great variability among transplant Centers.

In reported data in this review, Trypanosoma cruzi disease after heart transplantation occurred for reactivation in more than $80 \%$ (n 43/53) of cases.

Early diagnosis is needed [73,222], because of the high rate of morbidity and possible mortality, which are not however more relevant than in non-infected transplanted subjects. Indeed, survival probability for Chagasic heart transplant recipients at 1 month, 1 year, 4 year, and 10 year follow-ups are $83 \%, 71 \%, 57 \%$, and $46 \%$, respectively $[65,221]$, better than that seen in non Chagas' heart transplant recipients [221].

Like the native disease, acute, chronic, and reactivated trypanosomiasis in transplant recipients manifests with variable pattern from asymptomatic forms to life-threatening problems. Fever, myalgia, lymphadenopathy, hepatosplenomegaly and subcutaneous nodules are the most prevalent manifestations; less commonly meningoencephalitis and myocarditis can occur during the acute phase, while potentially lethal cardiomyopathy, megasyndrome (megaesophagus/megacolon), or both, can occur during the chronic phase. Complete heart block is a possibility, presenting clinical feature in patients with reactivation.

Diagnosis involves detection of circulating parasites by microscopic examination and blood culture in the acute phase, and by serology thereafter [73]. For heart transplantation, endomyocardial biopsy allows differentiation between graft rejection and parasitic disease. The pre-operative check-up with serological testing for T. cruzi of both transplant patients and donors is standard practice: [73] even asymptomatic persons testing positive are probably infectious for life, with low levels of parasite in blood and other tissues [73]. In case of mismatch donor/recipient, follow-up schedule and pre-emptive therapy must be performed to abate the parasitaemia and avoid clinical illness [65].

Benznidazole is the treatment of choice [3]. Nifurtimox is an effective alternative [3].

Malaria Plasmodium life cycle with a hepatic and an erythrocyte stage, allows the transmission of infection either with SOT or with blood transfusion, respectively. In such a setting, malaria remains a rare complication. However, post-transplantation malaria, although uncommon, must be considered particularly when either the recipient or the donor comes from a region endemic to malaria [90].

Primary infection or reinfection is a distinct risk in exposed transplant recipients. In published and available literature, post-transplant malaria reported cases involve kidney (16 cases, 59.3\%), liver ( 5 cases, $18.5 \%$ ), and heart ( 2 cases, $7.4 \%$ ) [83-92]. Among these patients, 13 had a primary infection due to well clarified transmission through allograft (n 11,40.7\%) or blood/blood products (n 1,3.7\%), and 1 patient (3.7\%) had a documented de novo infection. Nevertheless, in most of them the mechanisms of transmission were not clearly determined (n 14, 51.8\%).

The clinical picture of malaria in transplant recipients is usually severe, owing to the impaired immune response. It is characterized by pyrexia, which may lack the typical periodicity or rigors. Anemia is severe, being typically hemolytic and occasionally hemophagocytic. It is often associated with thrombocytopenia [86]. Hepatosplenic $\gamma \delta$-cell lymphoma probably attributed to malarial infection, has been described in kidney transplant recipients [223]. Acute graft dysfunction may occur as a result of the hemodynamic consequences of $P$. falciparum infection [224]. Whether the immune response 
to malarial infection has an impact on subsequent rejection is unknown. Diagnosis is confirmed by examination of a Giemsa- or acridine orange-stained peripheral blood smear. When parasitaemia is low, serological techniques using synthetic peptides as antigen [225] or DNA probes [226] are useful for diagnosis.

Antimalarial drugs can be used safely in most patients without incurring problems. However, certain drug-drug interactions must be taken into consideration such as those between quinine and chloroquine with CsA: quinine decreases CsA blood levels, chloroquine increases CsA blood levels [3]. This may be extrapolated to other immunosuppressive agents which depend on cytochrome P450 for their catabolism. Moreover, TAC together with chloroquine, artemisin combinations, or mefloquine increases the risk of arrhythmia [3].

Providing routine malaria prophylaxis probably is not necessary for SOT recipients on maintenance immunosuppressives [227].

In addition, a certain protective anti-malarial activity can be postulated from in vitro results obtained with immunosuppressive drugs, such as sirolimus and CsA. Instead, for the moment no conclusive data are available for everolimus and mycophenolic acid if tested at standard doses for the clinical use [3,228].

Beyond any possibility of tailored treatment (specific anti-malarial and selected immunosuppressive combined treatment), prevention and early individuation of at risk patients remains the most important measure.

In this context, careful anamnesis on epidemiological risk has to be seriously considered for each donor and recipient in both malaria endemic and non-endemic zones, considering that infection can still be acquired in non-endemic locations including European or American airports or autochthonous malarial foci $[229,230]$.

Babesiosis is a rare febrile disease, closely related to P. falciparum malaria, caused by piroplasmia Babesia, transmitted usually by tick bites. Babesiosis, attributed to graft or transfusion with contaminated blood, has been reported in four SOT recipients, three renal [94,96] and one cardiac [95]. In a further renal recipient affected by babesiosis, the mechanism of transmission has not been well clarified [93]. Fever, hemolytic anemia, and impaired graft function dominate the clinical picture in the kidney transplanted patient who acquired babesiosis through blood transfusion [94]; fever, fatigue and abdominal pain have been found in the two kidney transplanted patients acquiring parasitosis through the graft [96]; acute respiratory distress in the heart transplanted patient [95]; hemophagocytic syndrome has been reported in the latter, an asplenic renal transplant recipient [93]. Treatment consists of a combination of clindamycin and quinine, with therapeutic apheresis in severe cases [3].

Acanthamoebiasis is a protozoal disease caused by free-living amoebae.

Acanthamoeba castellanii typically complicates corneal transplantation leading to progressive keratitis, corneal opacities, or perforation [97]. It has also been reported in kidney [98,99,108], liver [105], lung [101,107], and multivisceral transplantation [100]. The total number of reported cases of post-SOT Acanthamoeba spp. infection amount to 17 cases. Disseminated acanthamoebiasis in transplant recipients is associated with gastroenteritis, sclerosing cholangitis, encephalitis [100,101,107], and osteomyelitis [99]. A fatal outcome has been reported in most disseminated cases.

Free-living ameba Balamutia mandrillaris has been reported as a cause of granulomatous amebic encephalitis. Infection with transplant-transmitted B. mandrillaris amebae was first identified by CDC reporting two clusters of infections in 2009 [103] and 2010 [104].

Balamuthia is known to spread hematogenously from extra-central nervous system (CNS) sites to the CNS [225]. Moreover, the described clusters of transplant transmission confirm that hematogenous spread of Balamuthia occurs from the CNS to other organs as well [231].

Lophomonas blattarum potentially leads to post-transplantation broncopneumonia. Initial symptoms can be relatively obscure. Thus, possible L. blattarum infection needs to be screened in patients with respiratory symptoms, especially in those who respond poorly to anti-infection treatment $[102,106]$. 
Intestinal protozoan parasitosis seems to be more common among transplant recipients compared to non-transplanted control subjects [134]: even parasites that are largely asymptomatic before transplantation may become clinically evident under immunosuppressive treatment.

Gastrointestinal disturbances, particularly diarrhea, both acute and chronic, are frequently observed complications in the first months following transplantation, potentially leading to a deterioration of the general health status in transplanted people. It is difficult to determine the exact etiology of the diarrhea in these patients, including drug-specific effects (i.e., mycophenolate mofetil, antibiotics, colchicines, laxative drug), metabolic conditions, mechanical complications of surgery, acute GVHD, as well as infectious agents (bacteria, such as Clostridium difficile, Campylobacter jejuni, Shigella sonnei and Salmonella enteritidis and virus, first of all CMV, but also Rotavirus, and parasites, in particular protozoan agents such as Cryptosporidium spp., Blastocystis spp., Giardia duodenalis, Entamoeba histolytica, Entamoeba coli, Endolimax nana, Iodamoeba butschili, Chilomastix mesnili, and Microsporidia spp.) [110-160].

In this scenario, the screening of samples for intestinal parasitic infections using direct smear, formalin-ether sedimentation, Sheather's flotation and modified Ziehl-Neelsen staining methods acquires extreme importance [232].

Colonoscopy with biopsy should be performed only after the implementation of available noninvasive testing for infectious diarrhea and upon evaluation of all medications taken, to assess the possible cause of diarrhea [114,131,232,233].

Intestinal protozoa can be difficult to eradicate even with specific treatment. Reduction in immunosuppressive regimen may hasten clearance of these durable pathogens [3].

Beyond localized syndrome, peri-transplant acquired or reactivated enteric protozoan parasitosis can also manifest as extra-intestinal (e.g., hepatobiliary) and systemic diseases because of their aggravation and/or dissemination [232].

Helminthic intestinal infections should be actively evaluated in solid organ transplant recipients in both pre- and post-transplant phase.

On the basis of published data, the most frequently intercurrent helminthic intestinal infection in SOT recipients seems to be strongyloidiasis $[15,161-191]$, being occasionally reported infections by other intestinal helminths such as Trichuris trichiura [192], Ascaris lumbricoides [134,193] and Dipylidium caninum [194].

As strongyloidiasis is a devastating complication of immunosuppression, SOT recipients can experience serious disease up to death from infection due to such a parasite.

Transplant recipients are at highest risk during the first three months post-transplant. Many organ systems may be affected, particularly in the case of autoinfection evolving in disseminated infection often complicated by polymicrobial sepsis due to enteric organisms adhering to the parasite.

Mortality is placed over 30\% [15,161-191], thus careful evaluation of patients at any risk of exposure is essential. Stool specimens as well sputum, urine, and duodenal aspirates may be examined for characteristic organisms. It has been suggested that stool examination become part of the pre-transplantation work-up in all patients, with a more extensive evaluation in patients with a history of travel to, or residence in, an area of endemic infection.

Dormant infection for over 10-20 years must also be considered. Prolonged corticosteroid use, either in the early post-transplant period or during treatment of rejection episodes, may reactivate dormant strongyloidiasis and promote its diffusion in infected hosts.

Regarding the treatment, ivermectin has been increasingly used, being effective, and even more so, tolerated, it represents the first line treatment [3]. Repeat courses may be needed to eradicate infection [3]. Albendazole represents the alternative treatment [3]. The use of CsA in prophylactic immunosuppression seems to reduce strongyloidiaisis occurrence thanks to a strong parasiticidal effect of the drug, which has been documented in mice and humans [3]. Conversely, tacrolimus seems to increase the risk of infection [3]. Consequently, treatment decisions should be made on a case-by-case basis. 
Taenia solium larva is the most common parasite affecting the CNS. It is unusual in transplant recipients, but the risk must be taken into account: neurocysticercosis (NCC) must be included in the differential diagnosis of patients with CNS involvement and intracranial space-occupying lesions (SOLs) along with tuberculosis (TB), toxoplasmosis, nocardiosis, fungal infections, and post-transplant lymphoproliferative disorder (PTLD) $[23,234]$. The temporal association of the infection with the time elapsed since transplantation, risk factors, clinical manifestations, and neuroimaging characteristics of the lesion can allow a reasoned and rational approach towards the recognition, diagnosis, and appropriate management [195,196,234].

\subsection{Non-Intestinal Helminths}

Schistosomes inhabit the portal (S. mansoni) or perivesical (S. haematobium) veins of humans often living silently in an infected host for decades. During schistosomular migration through the lymphatics to the bloodstream and/or the permanence of adult worms in the gastrointestinal and urinary tracts, the disease may be theoretically transmitted by blood transfusion or organ transplantation. Considering that patients with schistosomal infection are suitable recipients for kidney and liver transplantation, recrudescence is also possible. On the other hand, transplant recipients may be exposed to new infection or reinfection if exposure to contaminated water persists.

Schistosomiasis is a well-recognized cause of chronic liver disease and non-cirrhotic portal hypertension. Ova of S. mansoni and S. japonicum trapped in the hepatic microcirculation induce inflammation and fibrosis (e.g., granulomatous hepatitis and portal or "clay pipe-stem" fibrosis) through both direct hepatotoxicity and immune mediated damage [197,198,235].

Schistosomiasis can also induce glomerular lesions through immune-complex deposits containing schistosomal gut antigens. As a consequence, patients with schistosomal infection are subject to the risk of urological complications [235].

However, schistosomal infection is not a major risk factor for transplantation [235]. Therefore, infected patients can be considered as suitable recipients. Nevertheless, careful selection of kidney donors and recipients with appropriate antischistosomal treatment for at least one month before transplantation are highly recommended [236,237].

As regards echinococcosis (cystic and alveolar), transplantation of the involved organ should be regarded as a valuable treatment option. Recurrence inside and/or outside the transplanted organ is possible [199-203,237].

\subsection{Perspectives: When Parasitic Infections Become Protective for Transplant Recipients}

Several helminth-derived molecules have been able to modulate the host immune response [238].

Data obtained in animal model suggest that infection with the parasitic nematode Trichinella spiralis resulted in prolonged allograft survival following murine cardiac transplantation, with suppressed Th1/Th17 responses and augmented regulatory T cells [239].

Human data related to results of skin grafting in established schistosomiasis and more recent anecdotal suggestions of reduced immunosuppression requirement after liver transplantation for Echinococcus infection support the idea that helminth infection can enhance allograft tolerance. This is also demonstrated by multiple organ allograft animal models (e.g., mouse heart and skin; rat heart, liver, and kidney) [240]. As a consequence of such observations, the inclusion of specific live (non-pathogenic) helminth infection, or defined products from immunoregulatory helminths, in future transplantation protocols is now seriously considered as a potentially safe and effective alternative to current transplant immunosuppression regimens, burdened by multiple serious adverse effects and inadequate long-term organ protection against rejection [240]. Although treatment with active helminth infection has been shown to be a safe therapeutic approach [240], reports of mild gastrointestinal side effects do exist and might limit patient acceptability [241]. Further studies on this field are needed. 


\title{
6. Conclusions
}

Parasitic infectious diseases after SOT, especially renal, emerge as possible and increasing complications, associated with significant morbidity and mortality. New guidelines should be elaborated focusing on the following: (i) diagnosis of active and latent parasitic infections, and identification of risk factors for candidate; (ii) recommended approach for parasitic infections diagnosed during the evaluation process and their corresponding treatment; (iii) definition of parasitic infections contraindicating transplantation; and (iv) prevention of post-transplantation parasitic infectious complications by systematic prophylaxis or pre-emptive treatment and instructions on preventive measures provided to patients, their relatives, and persons living with them. Using a multidisciplinary approach that included the efforts of experts in the field and the collaboration of scientific Societies, a comprehensive document containing specific recommendations should be elaborated.

Author Contributions: All the authors conceived of the present research article, discussed the results and contributed to the final manuscript.

Funding: This research received no external funding.

Acknowledgments: We thank Alison Brewster for language assistance that improved the manuscript.

Conflicts of Interest: The authors declare no conflicts of interest.

\section{Abbreviations}

BAL

CNI

CNS

CsA

CSF

CMV

$\mathrm{D}+/ \mathrm{D}-$

HSCT

MTORI

NCC

PCR

PTLD

$\mathrm{R}+/ \mathrm{R}-$

SOLs

SOT

TAC

TB

TMP-SMZ

WB

\author{
bronchoalveolar lavage \\ calcineurin inhibitors \\ central nervous system \\ Cyclosporine \\ cerebral spinal fluid \\ Cytomegalovirus \\ Toxoplasma-seropositive/seronegative donor \\ allogeneic haematopoietic stem cell transplant \\ mammalian target of rapamycin inhibitors \\ Neurocysticercosis \\ polymerase chain reaction \\ post-transplant lymphoproliferative disorder \\ Toxoplasma-seropositive/seronegative recipient \\ intracranial space-occupying lesions \\ solid organ transplantation \\ Tacrolimus \\ Tuberculosis \\ trimethoprim-sulfamethoxazole \\ western blot
}

\section{References}

1. Barsoum, R.S. Parasitic infections in organ transplantation. Exp. Clin. Transplant. 2004, 2, 258-267. [PubMed]

2. Franco-Paredes, C.; Jacob, J.T.; Hidron, A.; Rodriguez-Morales, A.J.; Kuhar, D.; Caliendo, A.M. Transplantation and tropical infectious diseases. Int. J. Infect. Dis. 2010, 14, e189-e196. [CrossRef] [PubMed]

3. Kotton, C.N.; Lattes, R.; AST Infectious Diseases Community of Practice. Parasitic infections in solid organ transplant recipients. Am. J. Transplant. 2009, 9, S234-S251. [CrossRef] [PubMed]

4. Gallino, A.; Maggiorini, M.; Kiowski, W.; Martin, X.; Wunderli, W.; Schneider, J.; Turina, M.; Follath, F. Toxoplasmosis in heart transplant recipients. Eur. J. Clin. Microbiol. Infect. Dis. 1996, 15, 389-393. [CrossRef] [PubMed]

5. Renoult, E.; Georges, E.; Biava, M.F.; Hulin, C.; Frimat, L.; Hestin, D.; Kessler, M. Toxoplasmosis in kidney transplant recipients: Report of six cases and review. Clin. Infect. Dis. 1997, 24, 625-634. [CrossRef] [PubMed] 
6. Hermanns, B.; Brunn, A.; Schwarz, E.R.; Sachweh, J.S.; Seipelt, I.; Schroder, J.M.; Schröder, J.M.; Vogel, U.; Schoendube, F.A.; Buettner, R. Fulminant toxoplasmosis in a heart transplant recipient. Pathol. Res. Pract. 2001, 197, 211-215. [CrossRef] [PubMed]

7. Barcán, L.A.; Dallurzo, M.L.; Clara, L.O.; Valledor, A.; Macias, S.; Zorkin, E.; Gerona, S.; Livellara, B. Toxoplasma gondii pneumonia in liver transplantation: Survival after a severe case of reactivation. Transpl. Infect. Dis. 2002, 4, 93-96. [CrossRef] [PubMed]

8. Botterel, F.; Ichai, P.; Feray, C.; Bouree, P.; Saliba, F.; Tur Raspa, R.; Samuel, D.; Romand, S. Disseminated toxoplasmosis, resulting from infection of allograft, after orthotopic liver transplantation: Usefulness of quantitative PCR. J. Clin. Microbiol. 2002, 40, 1648-1650. [CrossRef] [PubMed]

9. Hommann, M.; Schotte, U.; Voigt, R.; Glutig, H.; Grube, T.; Kupper, B.; Konberg, A.; Richer, K.; Scheele, J. Cerebral toxoplasmosis after combined liver-pancreas-kidney and liver-pancreas transplantation. Transplant. Proc. 2002, 34, 2294-2295. [CrossRef]

10. Campbell, A.L.; Goldberg, C.L.; Magid, M.S.; Gondolesi, G.; Rumbo, C.; Herold, B.C. First case of toxoplasmosis following small bowel transplantation and systematic review of tissue-invasive toxoplasmosis following noncardiac solid organ transplantation. Transplantation 2006, 81, 408-417. [CrossRef] [PubMed]

11. Segall, L.; Moal, M.C.; Doucet, L.; Kergoat, N.; Bourbigot, B. Toxoplasmosis-associated hemophagocytic syndrome in renal transplantation. Transpl. Int. 2006, 19, 78-80. [CrossRef] [PubMed]

12. Assi, M.A.; Rosenblatt, J.E.; Marshall, W.F. Donor-transmitted toxoplasmosis in liver transplant recipients: A case report and literature review. Transpl. Infect. Dis. 2007, 9, 132-136. [CrossRef] [PubMed]

13. Castagnini, M.; Bernazzali, S.; Ginanneschi, C.; Marchi, B.; Maccherini, M.; Tsioulpas, C.; Tanganelli, P. Fatal disseminated toxoplasmosis in a cardiac transplantation with seropositive match for Toxoplasma: Should prophylaxis be extended? Transpl. Immunol. 2007, 18, 193-197. [CrossRef] [PubMed]

14. Sarchi, E.; Genco, F.; Di Matteo, A.; Castiglioni, B.; Minoli, L.; Meroni, V. Surveillance of Toxoplasma gondii infection in recipients of thoracic solid organ transplants. New Microbiol. 2007, 30, 299-302. [PubMed]

15. Valar, C.; Keitel, E.; Dal Prá, R.L.; Gnatta, D.; Santos, A.F.; Bianco, P.D.; Sukiennik, T.C.; Pegas, K.L.; Bittar, A.E.; Oliveira, K.T. Parasitic infection in renal transplant recipients. Transplant. Proc. 2007, 39, 460-462. [CrossRef] [PubMed]

16. Caner, A.; Döşkaya, M.; Karasu, Z.; Değirmenci, A.; Guy, E.; Kiliç, M.; Zeytunlu, M.; Francis, J.; Bozoklar, A.; Gürüz, Y. Incidence and diagnosis of active toxoplasma infection among liver transplant recipients in Western Turkey. Liver Transplant. 2008, 14, 1526-1532. [CrossRef] [PubMed]

17. Rogers, N.M.; Peh, C.A.; Faull, R.; Pannell, M.; Cooper, J.; Russ, G.R. Transmission of toxoplasmosis in two renal allograft recipients receiving an organ from the same donor. Transpl. Infect. Dis. 2008, 10, 71-74. [CrossRef] [PubMed]

18. Patrat-Delon, S.; Gangneux, J.P.; Lavoué, S.; Lelong, B.; Guiguen, C.; le Tulzo, Y.; Robert-Gagneux, F. Correlation of parasite load determined by quantitative PCR to clinical outcome in a heart transplant patient with disseminated toxoplasmosis. J. Clin. Microbiol. 2010, 48, 2541-2545. [CrossRef] [PubMed]

19. Sellami, H.; Amri, H.; Cheikhrouhou, F.; Sellami, A.; Makni, F.; Trabelsi, H.; Guermazi, M.; Ayadi, A. Toxoplasmosis in Sfax, Tunisia. Bull. Soc. Pathol. Exot 2010, 103, 37-40. [CrossRef] [PubMed]

20. Martina, M.N.; Cervera, C.; Esforzado, N.; Linares, L.; Torregrosa, V.; Sanclemente, G.; Hoyo, I.; Cofan, F.; Oppenheimer, F.; Miro, J.M.; et al. Toxoplasma gondii primary infection in renal transplant recipients. Two case reports and literature review. Transpl. Int. 2011, 24, e6-e12. [CrossRef] [PubMed]

21. Schmidt, M.; Sonneville, R.; Schnell, D.; Bigé, N.; Hamidfar, R.; Mongardon, N.; Castelain, V.; Razazi, K.; Marty, A.; Vincent, F.; et al. Clinical features and outcomes in patients with disseminated toxoplasmosis admitted to intensive care: A multicenter study. Clin. Infect. Dis. 2013, 57, 1535-1541. [CrossRef] [PubMed]

22. Vaughan, L.B.; Wenzel, R.P. Disseminated toxoplasmosis presenting as septic shock five weeks after renal transplantation. Transpl. Infect. Dis. 2013, 15, e20-e24. [CrossRef] [PubMed]

23. Bagchi, S.; Sachdev, S.S.; Nalwa, A.; Das, C.J.; Sinha, S.; Suri, V.; Mahajan, S.; Bhowmik, D.; Agarwal, S. Multiple intracranial space-occupying lesions in a renal transplant recipient from an area endemic for tuberculosis (TB): TB vs. toxoplasmosis. Transpl. Infect. Dis. 2014, 16, 838-842. [CrossRef] [PubMed]

24. Baliu, C.; Sanclemente, G.; Cardona, M.; Castel, M.A.; Perez-Villa, F.; Moreno, A.; Cervera, C. Toxoplasmic encephalitis associated with meningitis in a heart transplant recipient. Transpl. Infect. Dis. 2014, 16, 631-633. [CrossRef] [PubMed] 
25. Kervan, U.; Ozdamar, Y.; Yurdakok, O.; Kucuker, S.A.; Pac, M. A rare ocular complication after a heart transplant: Toxoplasma retinitis. Exp. Clin. Transplant. 2014, 12, 78-80. [CrossRef] [PubMed]

26. Rasti, S.; Hassanzadeh, M.; Soliemani, A.; Hooshyar, H.; Mousavi, S.G.; Nikoueinejad, H.; Adboli, A. Serological and molecular survey of toxoplasmosis in renal transplant recipients and hemodialysispatients in Kashan and Qom regions, central Iran. Ren. Fail. 2016, 38, 970-973. [CrossRef] [PubMed]

27. Miltgen, G.; Paillot, J.; Vanlemmens, C.; Di Martino, V.; Heyd, B.; Millon, L.; Bellanger, A.P. Fatal acute respiratory distress by Toxoplasma gondii in a toxoplasma seronegative liver transplant recipient. New Microbiol. 2016, 39, 160-162. [PubMed]

28. Esteban, R.J.; Bravo, J.A.; Osuna, A.; Asensio, C. Early antimoniate poisoning in a non-fatal visceral leishmaniasis kidney transplant recipient with renal failure. Nephrol. Dial. Transplant. 1996, 11, 1898. [CrossRef] [PubMed]

29. Sharma, R.K.; Jha, R.; Kumar, P.; Kher, V.; Gupta, A.; Kumar, A.; Gulati, S.; Arora, P.; Murari, M.; Bhandari, M. Visceral leishmaniasis in a renal transplant recipient: Diagnostic and therapeutic problems. Am. J. Nephrol. 1996, 16, 358-360. [CrossRef] [PubMed]

30. Apaydin, S.; Ataman, R.; Serdengect, K.; Tüzüner, N.; Polat, E.; Erek, E.; Ulku, U. Visceral leishmaniasis without fever in a kidney transplant recipient. Nephron 1997, 75, 241-242. [CrossRef] [PubMed]

31. Berenguer, J.; Go'mez-Campdera, F.; Padilla, B.; Padilla, B.; Rodríguez-Ferrero, M.; Anaya, F.; Moreno, S.; Valderràbano, F. Visceral leishmaniasis (Kala-Azar) in transplant recipients. Transplantation 1998, 65, 1401-1404. [CrossRef] [PubMed]

32. Roustan, G.; Jimenez, J.A.; Gutierrez-Solar, B.; Gallego, J.L.; Alvar, J.; Patron, M. Post-kala-azar dermal leishmaniasis with mucosal involvement in a kidney transplant recipient: Treatment with liposomal amphotericin B. Br. J. Dermatol. 1998, 138, 526-568. [CrossRef] [PubMed]

33. Boletis, J.N.; Pefanis, A.; Stathakis, C.; Helioti, H.; Kostakis, A.; Giamarellou, H. Visceral leishmaniasis in renal transplant recipients: Successful treatment with liposomal amphotericin B (AmBisome). Clin. Infect. Dis. 1999, 28, 1308-1309. [CrossRef] [PubMed]

34. Hernández-Pérez, J.; Yebra-Bango, M.; Jiménez-Martínez, E.; Sanz-Moreno, C.; Cuervas-Mons, V.; Alonso Pulpón, L.; Ramons-Martinez, A.; Fernandez-Fernandez, J. Visceral leishmaniasis (Kala-Azar) in solid organ transplantation: Report of five cases and review. Clin. Infect. Dis. 1999, 29, 918-921. [CrossRef] [PubMed]

35. Llorente, S.; Gimeno, L.; Navarro, M.J.; Moreno, S.; Rodriguez-Gironés, M. Therapy of visceral leishmaniasis in renal transplant recipients intolerant to pentavalent antimonials. Transplantation 2000, 70, 800-801. [CrossRef] [PubMed]

36. Frapier, J.M.; Abraham, B.; Dereure, J.; Albat, B. Fatal visceral leishmaniasis in a heart transplant recipient. J. Heart Lung Transplant. 2001, 20, 912-913. [CrossRef]

37. Pintado, V.; Martin-Rabadan, P.; Rivera, M.L.; Moreno, S.; Bouza, E. Visceral leishmaniasis in human immunodeficiency virus (HIV)-infected and non-HIV-infected patients: A comparative study. Medicine 2001, 80, 54-73. [CrossRef] [PubMed]

38. Fernandes, I.M.; Baptista, M.A.; Barbon, T.R.; Oliveira, J.F.; Oliveira, R.C.; Murai, N.M.; Camelo, F.C.; Ramalho, H.J.; Abbud-Filho, M. Cutaneous leishmaniasis in kidney transplant recipient. Transplant. Proc. 2002, 34, 504-505. [CrossRef]

39. Rajaram, K.G.; Sud, K.; Kohli, H.S.; Gupta, K.L.; Sakhuja, V. Visceral leishmaniasis: A rare cause of post-transplant fever and pancytopenia. J. Assoc. Physicians India 2002, 50, 979-980. [PubMed]

40. Sabbatini, M.; Pisani, A.; Ragosta, A.; Gallo, R.; Borrelli, F.; Cianciaruso, B. Visceral Leishmaniasis in renal transplant recipients: Is it still a challenge to the nephrologist? Transplantation 2002, 73, 299-301. [CrossRef] [PubMed]

41. Ersoy, A.; Güllülü, M.; Usta, M.; Ozçelik, T.; Ylmaz, E.; Uzaslan, E.K.; Vuruskan, H.; Yavuz, M.; Oktay, B.; Dilek, K.; et al. A renal transplant recipient with pulmonary tuberculosis and visceral leishmaniasis: Review of superimposed infections and therapy approaches. Clin. Nephrol. 2003, 60, 289-294. [CrossRef] [PubMed]

42. Morales, P.; Torres, J.J.; Salavert, M.; Peman, J.; Lacruz, J.; Sole, A. Visceral leishmaniasis in lung transplantation. Transplant. Proc. 2003, 35, 2001-2003. [CrossRef]

43. Halkic, N.; Ksontini, R.; Scholl, B.; Blanc, C.; Kovacsovics, T.; Meylan, P.; Muheim, C.; Gillet, M.; Mosimann, F. Recurrent cytomegalovirus disease, visceral leishmaniosis, and Legionella pneumonia after livertransplantation: A case report. Can. J. Anaesth. 2004, 51, 84-87. [CrossRef] [PubMed] 
44. Murray, H.W.; Berman, J.D.; Davies, C.R.; Saravia, N.G. Advances in leishmaniasis. Lancet 2005, 366, 1561-1577. [CrossRef]

45. Mirzabeigi, M.; Farooq, U.; Baraniak, S.; Dowdy, L.; Ciancio, G.; Vincek, V. Reactivation of dormant cutaneous Leishmania infection in a kidney transplant patient. J. Cutan. Pathol. 2006, 33, 701-704. [CrossRef] [PubMed]

46. Clemente, W.T.; Couto, C.A.; Ribeiro, D.D.; de Medeiros Chaves Franca, M.; Sanches, M.D. An atypical course of visceral leishmaniasis (Kala-Azar) in a liver transplant recipient. Transplantation 2007, 83, 368-369. [CrossRef] [PubMed]

47. Ozcan, D.; Seckin, D.; Allahverdiyev, A.M.; Weina, P.J.; Aydin, H.; Ozcay, F.; Heberal, M. Liver transplant recipient with concomitant cutaneous and visceral leishmaniasis. Pediatr. Transplant. 2007, 11, 228-232. [CrossRef] [PubMed]

48. Campos-Varela, I.; Len, O.; Castells, L.; Tallada, N.; Ribera, E.; Dopazo, C.; Vargas, V.; Gavaldà, J.; Charco, R. Visceral leishmaniasis among liver transplant recipients: An overview. Liver Transplant. 2008, 14, 1816-1819. [CrossRef] [PubMed]

49. Oliveira, C.M.; Oliveira, M.L.; Andrade, S.C.; Girão, E.S.; Ponte, C.N.; Mota, M.U.; Fernandes, P.F.; Campos, H.H.; Esmeraldo, R.M.; Evangelista, J.B., Jr. Visceral leishmaniasis in renal transplant recipients: Clinical aspects, diagnostic problems, and response to treatment. Transplant. Proc. 2008, 40, 755-760. [CrossRef] [PubMed]

50. Dettwiler, S.; McKee, T.; Hadaya, K.; Chappuis, F.; van Delden, C.; Moll, S. Visceral leishmaniasis in a kidney transplant recipient: Parasitic interstitial nephritis, a cause of renal dysfunction. Am. J. Transplant. 2010, 10, 1486-1489. [CrossRef] [PubMed]

51. Simon, I.; Wissing, K.M.; Del Marmol, V.; Antinori, S.; Remmelink, M.; Nilufer Broeders, E.; Nortier, J.L.; Corbellino, M.; Abramowicz, D.; Cascio, A. Recurrent leishmaniasis in kidney transplant recipients: Report of 2 cases and systematic review of the literature. Transpl. Infect. Dis. 2011, 13, 397-406. [CrossRef] [PubMed]

52. Alves da Silva, A.; Pacheco-Silva, A.; de Castro Cintra Sesso, R.; Esmeraldo, R.M.; Costa de Oliveira, C.M.; Fernandes, P.F.; Oliveira, R.A.; Silva, L.S.; Carvalho, V.P.; Nery Costa, C.H. The risk factors for and effects of visceral leishmaniasis in graft and renal transplant recipients. Transplantation 2013, 95, 721-727. [CrossRef] [PubMed]

53. Bouchekoua, M.; Trabelsi, S.; Ben Abdallah, T.; Khaled, S. Visceral leishmaniasis after kidney transplantation: Report of a new case and a review of the literature. Transplant. Rev. 2014, 28, 32-35. [CrossRef] [PubMed]

54. Pedroso, J.A.; Paola Salerno, M.; Spagnoletti, G.; Bertucci-Zoccali, M.; Zaccone, G.; Bianchi, V.; Romagnoli, J.; Citterio, F. Elderly kidney transplant recipient with intermittent fever: A case report of leishmaniasis with acute kidney injury during liposomal amphotericin B therapy. Transplant. Proc. 2014, 46, 2365-2367. [CrossRef] [PubMed]

55. Clemente, W.; Vidal, E.; Girão, E.; Ramos, A.S.; Govedic, F.; Merino, E.; Muñoz, P.; Sabé, N.; Cervera, C.; Cota, G.F.; et al. Risk factors, clinical features and outcomes of visceral leishmaniasis in solid-organ transplant recipients: A retrospective multicenter case-control study. Clin. Microbiol. Infect. 2015, 21, 89-95. [CrossRef] [PubMed]

56. De Silva, A.A.; Pacheco e Silva Filho, Á.; Sesso Rde, C.; Esmeraldo Rde, M.; de Oliveira, C.M.; Fernandes, P.F.; de Oliveira, R.A.; de Silva, L.S.; de Carvalho, V.P.; Costa, C.H.; et al. Epidemiologic, clinical, diagnostic and therapeutic aspects of visceral leishmaniasis in renaltransplant recipients: Experience from thirty cases. BMC Infect. Dis. 2015, 15, 96. [CrossRef] [PubMed]

57. Duvignaud, A.; Receveur, M.C.; Ezzedine, K.; Pistone, T.; Malvy, D. Visceral leishmaniasis due to Leishmania infantum in a kidney transplant recipient living in France. Travel Med. Infect. Dis. 2015, 13, 115-116. [CrossRef] [PubMed]

58. Ramos, A.; Múñez, E.; García-Domínguez, J.; Martinez-Ruiz, R.; Chicharro, C.; Baños, I.; Suarez-Massa, D.; Cuervas-Mons, V. Mucosal leishmaniasis mimicking squamous cell carcinoma in a liver transplant recipient. Transpl. Infect. Dis. 2015, 17, 488-492. [CrossRef] [PubMed]

59. Arze, S.; Arze, L.; Abecia, C. Post-transplantation Infections in Bolivia. Transplant. Proc. 2016, 48, 646-653. [CrossRef] [PubMed]

60. Opota, O.; Balmpouzis, Z.; Berutto, C.; Kaiser-Guignard, J.; Greub, G.; Aubert, J.D.; Prod'hom, G.; Manuel, O.; Jaton, K. Visceral leishmaniasis in a lung transplant recipient: Usefulness of highly sensitive real-time polymerase chain reaction for preemptive diagnosis. Transpl. Infect. Dis. 2016, 18, 801-804. [CrossRef] [PubMed] 
61. Amato, J.G.; Amato Neto, V.; Amato, V.S.; Duarte, M.I.; Uip, D.E.; Boulos, M. Cutaneous lesions as the only manifestations of reactions to Trypanosoma cruzi infection in a recipient of a kidney transplant. Rev. Soc. Bras. Med. Trop. 1996, 30, 61-63. [CrossRef]

62. Carvalho, M.F.; de Franco, M.F.; Soares, V.A. Amastigotes forms of Trypanosoma cruzi detected in a renal allograft. Rev. Inst. Med. Trop. Sao Paulo 1997, 39, 223-226. [CrossRef] [PubMed]

63. Tomimori-Yamashita, J.; Deps, P.D.; Almeida, D.R.; Enokihara, M.M.; De Seixas, M.T.; Freymuller, E. Cutaneous manifestation of Chagas' disease after heart transplantation: Successful treatment with allopurinol. Br. J. Dermatol. 1997, 137, 626-630. [CrossRef] [PubMed]

64. Riarte, A.; Luna, C.; Sabatiello, R.; Sinagra, A.; Schiavelli, R.; De Rissio, A.; Maiolo, E.; Garcìa, M.M.; Jacob, N.; Pattin, M.; et al. Chagas' disease in patients with kidney transplants: 7 years of experience 1989-1996. Clin. Infect. Dis. 1999, 29, 561-567. [CrossRef] [PubMed]

65. Bocchi, E.A.; Fiorelli, A. The paradox of survival results after heart transplantation for cardiomyopathy caused by Trypanosoma cruzi. First Guidelines Group for Heart Transplantation of the Brazilian Society of Cardiology. Ann. Thorac. Surg. 2001, 71, 1833-1838. [CrossRef]

66. De Souza, M.; Franco, M.; Almeida, D.R.; Diniz, R.V.; Mortara, R.A.; da Silva, S.; Reis da Silva Patrício, F. Comparative histopathology of endomyocardial biopsies in chagasic and non chagasic heart transplant recipients. J. Heart Lung Transplant. 2001, 20, 534-543. [CrossRef]

67. Centers for Disease Control and Prevention (CDC). Chagas disease after organ transplantation-United States, 2001. Morb. Mortal. Wkly. Rep. 2002, 51, 210-212.

68. La Forgia, M.P.; Pellerano, G.; de las Mercedes Portaluppi, M.; Kien, M.C.; Chouela, E.N. Cutaneous manifestation of reactivation of Chagas disease in a renal transplant patient: Long-term follow-up. Arch. Dermatol. 2003, 139, 104-105. [CrossRef] [PubMed]

69. Bestetti, R.B.; Cury, P.M.; Theodoropoulos, T.A.; Villafanha, D. Trypanosoma cruzi myocardial infection reactivation presenting as complete atrioventricular block in a Chagas' heart transplant recipient. Cardiovasc. Pathol. 2004, 13, 323-326. [CrossRef] [PubMed]

70. Maldonado, C.; Albano, S.; Vettorazzi, L.; Salomone, O.; Zlocowski, J.C.; Abiega, C.; Amuchastegui, M.; Córdoba, R.; Alvarellos, T. Using polymerase chain reaction in early diagnosis of re-activated Trypanosoma cruzi infection after hearttransplantation. J. Heart Lung Transplant. 2004, 23, 1345-1348. [CrossRef] [PubMed]

71. Barcán, L.; Luna, C.; Clara, L.; Sinagra, A.; Valledor, A.; De Rissio, A.M.; Gadano, A.; García, M.M.; de Santibañes, E.; Riarte, A. Transmission of T. cruzi infection via liver transplantation to a nonreactive recipient for Chagas' disease. Liver Transplant. 2005, 11, 1112-1116. [CrossRef] [PubMed]

72. Centers for Disease Control and Prevention (CDC). Chagas disease after organ transplantation-Los Angeles, California, 2006. Morb. Mortal. Wkly. Rep. 2006, 55, 798-800.

73. Campos, S.V.; Strabelli, T.M.; Amato Neto, V.; Silva, C.P.; Bacal, F.; Bocchi, E.A.; Stolf, N.A. Risk factors for Chagas' disease reactivation after heart transplantation. J. Heart Lung Transplant. 2008, 27, 597-602. [CrossRef] [PubMed]

74. Souza, F.F.; Castro-E-Silva, O.; Marin Neto, J.A.; Sankarankutty, A.K.; Teixeira, A.C.; Martinelli, A.L.; Gaspar, G.G.; Melo, L.; Figueiredo, J.F.; Romano, M.M.; et al. Acute chagasic myocardiopathy after orthotopic liver transplantation with donor and recipient serologically negative for Trypanosoma cruzi: A case report. Transplant. Proc. 2008, 40, 875-878. [CrossRef] [PubMed]

75. Kun, H.; Moore, A.; Mascola, L.; Steurer, F.; Lawrence, G.; Kubak, B.; Radhakrishna, S.; Leiby, D.; Herron, R.; Mone, T.; et al. Transmission of Trypanosoma cruzi by heart transplantation. Clin. Infect. Dis. 2009, 48, 1534-1540. [CrossRef] [PubMed]

76. Silva, A.E.; Silva, A.C.; Faleiros, A.C.; Guimaraes, C.S.; Correa, R.R.; Oliveira, F.A.; Correia, D.; Teixeira, A.C.; Ramirez, L.E.; Teixeira Vde, P.; et al. Acute Chagas' disease in postrenal transplant and treatment with benzonidazole. Ann. Diagn. Pathol. 2010, 14, 199-203. [CrossRef] [PubMed]

77. Theodoropoulos, T.A.; Silva, A.G.; Bestetti, R.B. Eosinophil blood count and anemia are associated with Trypanosoma cruzi infection reactivation in Chagas' heart transplant recipients. Int. J. Cardiol. 2010, 145, 55-56. [CrossRef] [PubMed]

78. Salvador, F.; Len, O.; Molina, I.; Sulleiro, E.; Sauleda, S.; Bilbao, I.; Bilbao, I.; Castells, L.; Pont, T.; Gavaldà, J.; et al. Safety of liver transplantation performed with Chagas seropositive donors to seronegative recipients. Liver Transplant. 2011, 17, 1304-1308. [CrossRef] [PubMed] 
79. McCormack, L.; Quiñónez, E.; Goldaracena, N.; Anders, M.; Rodríguez, V.; Orozco Ganem, F.; Mastai, R.C. Liver transplantation using Chagas-infected donors in uninfected recipients: A single-center experience without prophylactic therapy. Am. J. Transplant. 2012, 12, 2832-2837. [CrossRef] [PubMed]

80. Cura, C.I.; Lattes, R.; Nagel, C.; Gimenez, M.J.; Blanes, M.; Calabuig, E.; Iranzo, A.; Barcan, L.A.; Anders, M.; Schijman, A.G. Early molecular diagnosis of acute Chagas disease after transplantation with organs from Trypanosoma cruzi-infected donors. Am. J. Transplant. 2013, 13, 3253-3261. [CrossRef] [PubMed]

81. Huprikar, S.; Bosserman, E.; Patel, G.; Moore, A.; Pinney, S.; Anyanwu, A.; Neofytos, D.; Ketterer, D.; Striker, R.; Silveira, F.; et al. Donor-derived Trypanosoma cruzi infection in solid organ recipients in the United States, 2001-2011. Am. J. Transplant. 2013, 13, 2418-2425. [CrossRef] [PubMed]

82. Cicora, F.; Escurra, V.; Bibolini, J.; Petroni, J.; González, I.; Roberti, J. Cerebral trypanosomiasis in a renal transplant recipient. Transpl. Infect. Dis. 2014, 16, 813-817. [CrossRef] [PubMed]

83. Talabiska, D.G.; Komar, M.J.; Wytok, D.H.; Rubin, R.A. Posttransfusion acquired malaria complicating orthotopic liver transplantation. Am. J. Gastroenterol. 1996, 91, 376-379. [PubMed]

84. Turkmen, A.; Sever, M.S.; Ecder, T.; Yildiz, A.; Aydin, A.E.; Erkoc, R.; Eraksoy, H.; Eldegez, U.; Ark, E. Posttransplant malaria. Transplantation 1996, 62, 1521-1523. [CrossRef] [PubMed]

85. Fischer, L.; Sterneck, M.; Claus, M.; Costard-Jackle, A.; Fleischer, B.; Herbst, H.; Rogiers, X.; Broelsch, C.E. Transmission of malaria tertiana by multiorgan donation. Clin. Transpl. 1999, 13, 491-495. [CrossRef]

86. Nuesch, R.; Cynke, E.; Jost, M.C.; Zimmerli, W. Thrombocytopenia after kidney transplantation. Am. J. Kidney Dis. 2000, 35, 537-538. [CrossRef]

87. Chiche, L.; Lesage, A.; Duhamel, C.; Salame, E.; Malet, M.; Samba, D.; Segol, P.; Treilhaud, M. Post-transplant malaria: First case of transmission of Plasmodium falciparum from a white multiorgan donor to four recipients. Transplantation 2003, 75, 166-168. [CrossRef] [PubMed]

88. Moran, E.; Collins, L.; Clayton, S.; Peto, T.; Bowler, I.C. Case of cryptic malaria. Commun. Dis. Public Health 2004, 7, 142-144. [PubMed]

89. Menichetti, F.; Bindi, M.L.; Tascini, C.; Urbani, L.; Biancofiore, G.; Doria, R.; Esposito, M.; Mozzo, R.; Catalano, G.; Filipponi, F. Fever, mental impairment, acute anemia, and renal failure in patient undergoing orthotopic liver transplantation: Posttransplantation malaria. Liver Transplant. 2006, 12, 674-676. [CrossRef] [PubMed]

90. Pandey, D.; Lee, K.H.; Wong, S.Y.; Tan, K.C. Malaria after living donor liver transplantation: Report of two cases. Hepatobiliary Pancreat Dis. Int. 2008, 7, 210-213. [PubMed]

91. Kute, V.B.; Vanikar, A.V.; Shah, P.R.; Shrimali, J.D.; Gumber, M.R.; Patel, H.V.; Modi, P.R.; Trivedi, H.L. Postrenal transplant Plasmodium vivax malaria: Neglected and not benign. Parasitol. Res. 2013, 112, 1791-1793. [CrossRef] [PubMed]

92. Sabé, N.; González-Costello, J.; Oriol, I.; Sánchez-Salado, J.C.; Ortega, S.; Oliver, E.; Manito, N.; Carratalà, J. Donor-transmitted malaria after heart transplant managed successfully with artesunate. Transpl. Infect. Dis. 2014, 16, 999-1002. [CrossRef] [PubMed]

93. Slovut, D.P.; Benedetti, E.; Matas, A.J. Babesiosis and hemophagocytic syndrome in an asplenic renal transplant recipient. Transplantation 1996, 62, 537-539. [CrossRef] [PubMed]

94. Perdrizet, G.A.; Olson, N.H.; Krause, P.J.; Banever, G.T.; Spielman, A.; Cable, R.G. Babesiosis in a renal transplant recipient acquired through blood transfusion. Transplantation 2000, 70, 205-208. [PubMed]

95. Lux, J.Z.; Weiss, D.; Linden, J.V.; Kessler, D.; Herwaldt, B.L.; Wong, S.J.; Keithly, J.; Della-Latta, P.; Scully, B.E. Transfusion-associated babesiosis after heart transplant. Emerg. Infect. Dis. 2003, 9, 116-119. [CrossRef] [PubMed]

96. Brennan, M.B.; Herwaldt, B.L.; Kazmierczak, J.J.; Weiss, J.W.; Klein, C.L.; Leith, C.P.; He, R.; Oberley, M.J.; Tonnetti, L.; Wilkins, P.P.; et al. Transmission of Babesia microti Parasites by Solid Organ Transplantation. Emerg. Infect. Dis. 2016, 22. [CrossRef] [PubMed]

97. Illingworth, C.D.; Cook, S.D. Acanthamoeba keratitis. Surv. Ophthalmol. 1998, 42, 493-508. [CrossRef]

98. Oliva, S.; Jantz, M.; Tiernan, R.; Cook, D.L.; Judson, M.A. Successful treatment of widely disseminated acanthamoebiasis. South. Med. J. 1999, 92, 55-57. [CrossRef] [PubMed]

99. Steinberg, J.P.; Galindo, R.L.; Kraus, E.S.; Ghanem, K.G. Disseminated Acanthamebiasis in a Renal transplant Recipient with Osteomyelitis and Cutaneous Lesions: Case Report and Literature Review. Clin. Infect. Dis. 2002, 35, e43-e49. [CrossRef] [PubMed] 
100. Mendez, O.; Kanal, E.; Abu-Elmagd, K.M.; McFadden, K.; Thomas, S.; Bond, G.; Zivkovic, S.A. Granulomatous amebic encephalitis in a multivisceral transplant recipient. Eur. J. Neurol. 2006, 13, 292-295. [CrossRef] [PubMed]

101. Duarte, A.G.; Sattar, F.; Granwehr, B.; Aronson, J.F.; Wang, Z.; Lick, S. Disseminated Acanthamoebiasis after lung transplantation. J. Heart Lung Transplant. 2006, 25, 237-240. [CrossRef] [PubMed]

102. Wang, Y.; Tang, Z.; Ji, S.; Zhang, Z.; Chen, J.; Cheng, Z.; Cheng, D.; Liu, Z.; Li, L. Pulmonary Lophomonas blattarum infection in patients with kidney allograft transplantation. Transpl. Int. 2006, 19, 1006-1013. [CrossRef] [PubMed]

103. Centers for Disease Control and Prevention (CDC). Balamuthia mandrillaris transmitted through organ transplantation-Mississippi, 2009. Morb. Mortal. Wkly. Rep. 2010, 59, 1165-1170.

104. Centers for Disease Control and Prevention (CDC). Notes from the field: Transplant-transmitted Balamuthia mandrillaris-Arizona, 2010. Morb. Mortal. Wkly. Rep. 2010, 59, 1182.

105. Young, A.L.; Leboeuf, N.R.; Tsiouris, S.J.; Husain, S.; Grossman, M.E. Fatal disseminated Acanthamoeba infection in a liver transplant recipient immunocompromised by combination therapies for graft-versus-host disease. Transpl. Infect. Dis. 2010, 12, 529-537. [CrossRef] [PubMed]

106. He, Q.; Chen, X.; Lin, B.; Qu, L.; Wu, J.; Chen, J. Late onset pulmonary Lophomonas blattarum infection in renal transplantation: A report of two cases. Intern. Med. 2011, 50, 1039-1043. [CrossRef] [PubMed]

107. Afshar, K.; Boydking, A.; Ganesh, S.; Herrington, C.; McFadden, P.M. Rapidly fatal disseminated acanthamoebiasis in a single lung transplant recipient. Ann. Transplant. 2013, 18, 108-111. [CrossRef] [PubMed]

108. Satlin, M.J.; Graham, J.K.; Visvesvara, G.S.; Mena, H.; Marks, K.M.; Saal, S.D.; Soave, R. Fulminant and fatal encephalitis caused by Acanthamoeba in a kidney transplant recipient: Case report and literature review. Transpl. Infect. Dis. 2013, 15, 619-626. [CrossRef] [PubMed]

109. Gupte, A.A.; Hocevar, S.N.; Lea, A.S.; Kulkarni, R.D.; Schain, D.C.; Casey, M.J.; Zendejas-Ruiz, I.R.; Chung, W.K.; Mbaeyi, C.; Roy, S.L.; et al. Transmission of Balamuthia mandrillaris through solid organ transplantation: Utility of organ recipient serology to guide clinical management. Am. J. Transplant. 2014, 14, 1417-1424. [CrossRef] [PubMed]

110. Ok, U.Z.; Cirit, M.; Uner, A.; Ok, E.; Akçiçek, F.; Başçi, A.; Ozcel, M.A. Cryptosporidiosis and blastocystosis in renal transplant recipients. Nephron 1997, 75, 171-174. [CrossRef] [PubMed]

111. Chieffi, P.P.; Sens, Y.A.; Paschoalotti, M.A.; Miorin, L.A.; Silva, H.G.; Jabur, P. Infection by Cryptosporidium parvum in renal patients submitted to renal transplant or hemodialysis. Rev. Soc. Bras. Med. Trop. 1998, 31, 333-337. [CrossRef] [PubMed]

112. Campos, M.; Jouzdani, E.; Sempoux, C.; Buts, J.P.; Reding, R.; Otte, J.B.; Sokal, E.M. Sclerosing cholangitis associated to cryptosporidiosis in liver-transplanted children. Eur. J. Pediatr. 2000, 159, 113-115. [CrossRef] [PubMed]

113. Gerber, D.A.; Green, M.; Jaffe, R.; Greenberg, D.; Mazariegos, G.; Reyes, J. Cryptosporidial infections after solid organ transplantation in children. Pediatr. Transplant. 2000, 4, 50-55. [CrossRef] [PubMed]

114. Delis, S.G.; Tector, J.; Kato, T.; Mittal, N.; Weppler, D.; Levi, D.; Ruiz, P.; Nishida, S.; Nery, J.R.; Tzakis, A.G. Diagnosis and treatment of cryptosporidium infection in intestinal transplant recipients. Transplant. Proc. 2002, 34, 951-952. [CrossRef]

115. Abdo, A.; Klassen, J.; Urbanski, S.; Raber, E.; Swain, M.G. Reversible sclerosing cholangitis secondary to cryptosporidiosis in a renal transplant patient. J. Hepatol. 2003, 38, 688-691. [CrossRef]

116. Pozio, E.; Rivasi, F.; Caccio, S.M. Infection with Cryptosporidium hominis and reinfection with Cryptosporidium parvum in a transplanted ileum. APMIS 2004, 112, 309-313. [CrossRef] [PubMed]

117. Udgiri, N.; Minz, M.; Kashyap, R.; Heer, M.; Gupta, C.S.; Mohandas, K.; Minz, R.W.; Malla, N. Intestinal cryptosporidiasis in living related renal transplant recipients. Transplant. Proc. 2004, 36, 2128-2129. [CrossRef] [PubMed]

118. Tran, M.Q.; Gohh, R.Y.; Morrissey, P.E.; Dworkin, L.D.; Gautam, A.; Monaco, A.P.; Yango, A.F., Jr. Cryptosporidium infection in renal transplant patients. Clin. Nephrol. 2005, 63, 305-309. [CrossRef] [PubMed]

119. Ziring, D.; Tran, R.; Edelstein, S.; McDiarmid, S.V.; Gajjar, N.; Cortina, G.; Vargas, J.; Renz, J.F.; Cherry, J.D.; Krogstad, P.; et al. Infectious enteritis after intestinal transplantation: Incidence, timing, and outcome. Transplantation 2005, 79, 702-709. [CrossRef] [PubMed] 
120. Franco, A.; Rocamora, N.; Merino, E.; Paya, A. Cryptosporidiosis. A rare infection in renal transplantation. Nefrologia 2006, 26, 753-754. [PubMed]

121. Arslan, H.; Inci, E.K.; Azap, O.K.; Karakayali, H.; Torgay, A.; Haberal, M. Etiologic agents of diarrhea in solid organ recipients. Transpl. Infect. Dis. 2007, 9, 270-275. [CrossRef] [PubMed]

122. Hong, D.K.; Wong, C.J.; Gutierrez, K. Severe cryptosporidiosis in a seven-year-old renal transplant recipient: Case report and review of the literature. Pediatr. Transplant. 2007, 11, 94-100. [CrossRef] [PubMed]

123. Denkinger, C.M.; Harigopal, P.; Ruiz, P.; Dowdy, L.M. Cryptosporidium parvum-associated sclerosing cholangitis in a liver transplant patient. Transpl. Infect. Dis. 2008, 10, 133-136. [CrossRef] [PubMed]

124. Bandin, F.; Kwon, T.; Linas, M.D.; Guigonis, V.; Valentin, A.; Cassaing, S.; Carol, A.; Garnier, A.; Baudouin, V.; Decramer, S. Cryptosporidiosis in paediatric renal transplantation. Pediatr. Nephrol. 2009, 24, 2245-2255. [CrossRef] [PubMed]

125. Bednarska, M.; Bajer, A.; Graczyk, T.K.; Sinski, E. Opportunistic parasites in immunocompetent and immunodeficient patients with diarrhea. In Proceedings of the 3rd International Giardia and Cryptosporidium Conference, Orvieto, Italy, 11-15 October 2009; Istituto Superiore di Sanita: Rome, Italy, 2009.

126. Rodríguez Ferrero, M.L.; Muñoz, P.; Valerio, M.; Bouza, E.; Martín-Rabadán, P.; Anaya, F. Cryptosporidium parvum infection in a kidney transplant recipient. Nefrologia 2010, 30, 476-477. [CrossRef] [PubMed]

127. Frei, P.; Weber, A.; Geier, A.; Mertens, J.C.; Kohler, S.; Rogler, G.; Mullhaupt, B. Lessons from a transplant patient with diarrhea, cryptosporidial infection, and possible mycophenolate mofetil-associated colitis. Transpl. Infect. Dis. 2011, 13, 416-418.

128. Acikgoz, Y.; Ozkaya, O.; Bek, K.; Genc, G.; Sensoy, S.G.; Hokelek, M. Cryptosporidiosis: A rare and severe infection in a pediatric renal transplant recipient. Pediatr. Transplant. 2012, 16, e115-e119. [CrossRef] [PubMed]

129. Bonatti, H.; Barroso, L.F.; Sawyer, R.G.; Kotton, C.N.; Sifri, C.D. Cryptosporidium enteritis in solid organ transplant recipients: Multicenter retrospective evaluation of 10 cases reveals an association with elevated tacrolimus concentrations. Transpl. Infect. Dis. 2012, 14, 635-648. [CrossRef] [PubMed]

130. Krause, I.; Amir, J.; Cleper, R.; Dagan, A.; Behor, J.; Samra, Z.; Davidovits, M. Cryptosporidiosis in children following solid organ transplantation. Pediatr. Infect. Dis. J. 2012, 31, 1135-1138. [CrossRef] [PubMed]

131. Bhadauria, D.; Goel, A.; Kaul, A.; Sharma, R.K.; Gupta, A.; Ruhela, V.; Gupta, A.; Vardhan, H.; Prasad, N. Cryptosporidium infection after renal transplantation in an endemic area. Transpl. Infect. Dis. 2015, 17, 48-55. [CrossRef] [PubMed]

132. Lanternier, F.; Amazzough, K.; Favennec, L.; Mamzer-Bruneel, M.F.; Abdoul, H.; Touret, J.; Decramer, S.; Zuber, J.; Scemla, A.; Legendre, C.; et al. Cryptosporidium spp. Infection in Solid Organ Transplantation: The Nationwide "TRANSCRYPTO" Study. Transplantation 2016, 101, 826-830. [CrossRef] [PubMed]

133. Rao, K.; Sekar, U.; Iraivan, K.T.; Abraham, G.; Soundararajan, P. Blastocystis hominis-An emerging cause of diarrhoea in renal transplant recipients. J. Assoc. Physicians India 2003, 51, 719-721. [PubMed]

134. Azami, M.; Sharifi, M.; Hejazi, S.H.; Tazhibi, M. Intestinal parasitic infections in renal transplant recipients. Braz. J. Infect. Dis. 2010, 14, 15-18. [CrossRef]

135. Kristensen, A.A.; Horneland, R.; Birn, H.; Svensson, M. Giardia lamblia infection after pancreas-kidney transplantation. BMJ Case Rep. 2016, 2016, bcr2015211515. [CrossRef] [PubMed]

136. Rabodonirina, M.; Bertocchi, M.; Desportes-Livage, I.; Cotte, L.; Levrey, H.; Piens, M.A.; Monneret, G.; Celard, M.; Mornex, J.F.; Mojon, M. Enterocytozoon bieneusi as a cause of chronic diarrhea in a heart-lung transplant recipient who was seronegative for human immunodeficiency virus. Clin. Infect. Dis. 1996, 23, 114-117. [CrossRef] [PubMed]

137. Guerard, A.; Rabodonirina, M.; Cotte, L.; Liguory, O.; Piens, M.A.; Daoud, S.; Picot, S.; Touraine, J.L. Intestinal microsporidiosis occurring in two renal transplant recipients treated with mycophenolate mofetil. Transplantation 1999, 68, 699-707. [CrossRef] [PubMed]

138. Gumbo, T.; Hobbs, R.E.; Carlyn, C.; Hall, G.; Isada, C.M. Microsporidia infection in transplant patients. Transplantation 1999, 67, 482-484. [CrossRef] [PubMed]

139. Metge, S.; Tran Van Nhieu, J.; Dahmane, D.; Grimbert, P.; Foulet, F.; Sarfati, C.; Bretagne, S. A case of Enterocytozoon bieneusi infection in an, H.I.V-negative renal transplant recipient. Eur. J. Microbiol. Infect. Dis. 2000, 19, 221-223. [CrossRef]

140. Goetz, M.; Eichenlaub, S.; Pape, G.R.; Hoffmann, R.M. Chronic diarrhea as a result of intestinal microsposidiosis in a liver transplant recipient. Transplantation 2001, 71, 334-337. [CrossRef] [PubMed] 
141. Liguory, O.; Sarfati, C.; Derouin, F.; Molina, J.M. Evidence of different Enterocytozoon bieneusi genotypes in patients with and without human immunodeficiency virus infection. J. Clin. Microbiol. 2001, 39, 2672-2674. [CrossRef] [PubMed]

142. Sing, A.; Tybus, K.; Heesemann, J.; Mathis, A. Molecular diagnosis of an Enterocytozoon bieneusi human genotype $\mathrm{C}$ infection in a moderately immunosuppressed human immunodeficiency virus-seronegative liver-transplant recipient with severe chronic diarrhea. J. Clin. Microbiol. 2001, 39, 2371-2372. [CrossRef] [PubMed]

143. Latib, M.A.; Pascoe, M.D.; Duffield, M.S.; Kahn, D. Microsporidiosis in the graft of a renal transplant recipient. Transpl. Int. 2001, 14, 274-277. [CrossRef] [PubMed]

144. Molina, J.M.; Tourneur, M.; Sarfati, C.; Chevret, S.; de Gouvello, A.; Gobert, J.G.; Balkan, S.; Derouin, F. Agence Nationale de Recherches sur le, SIDA. 090 Study Group. Fumagillin treatment of intestinal microsporidiosis. N. Engl. J. Med. 2002, 346, 1963-1969. [CrossRef] [PubMed]

145. Mohindra, A.R.; Lee, M.W.; Visvesvara, G.; Moura, H.; Parasuraman, R.; Leitch, G.J.; Xiao, L.; Yee, J.; del Busto, R. Disseminated microsporidiosis in a renal transplant recipient. Transpl. Infect. Dis. 2002, 4, 102-107. [CrossRef] [PubMed]

146. Gamboa-Dominguez, A.; De Anda, J.; Donis, J.; Ruiz-Maza, F.; Visvesvara, G.S.; Diliz, H. Disseminated Encephalitozoon cuniculi infection in a Mexican kidney transplant recipient. Transplantation 2003, 75, 1898-1900. [CrossRef] [PubMed]

147. Mahmood, M.N.; Keohane, M.E.; Burd, E.M. Pathologic quiz case: A 45-year-old renal transplant recipient with persistent fever. Arch. Pathol. Lab. Med. 2003, 127, e224-e226. [PubMed]

148. Rabodonirina, M.; Cotte, L.; Radenne, L.; Besada, E.; Trepo, C. Microsporidiosis and transplantation: A retrospective study of 23 cases. J. Eukaryot. Microbiol. 2003, 50, S583. [CrossRef]

149. Carlson, J.R.; Li, L.; Helton, C.L.; Munn, R.J.; Wasson, K.; Perez, R.V.; Gallay, B.J.; Finkbeiner, W.E. Disseminated microsporidiosis in a pancreas/kidney transplant recipient. Arch. Pathol. Lab. Med. 2004, 128, e41-e43. [PubMed]

150. Kakrania, R.; Joseph, J.; Vaddavalli, P.K.; Gangopadhyay, N.; Sharma, S. Microsporidia keratoconjunctivitis in a corneal graft. Eye 2006, 20, 1314-1315. [CrossRef] [PubMed]

151. Arzouk, N.; Michelon, H.; Snanoudj, R.; Taburet, A.M.; Durrbach, A.; Furlan, V. Interaction between tacrolimus and fumagillin in two kidney transplant recipients. Transplantation 2006, 81, 136-137. [CrossRef] [PubMed]

152. Ten Hove, R.J.; Van Lieshout, L.; Beadsworth, M.B.; Perez, M.A.; Spee, K.; Claas, E.C.; Verwejj, J.J. Characterization of genotypes of Enterocytozoon bieneusi in immunosuppressed and immunocompetent patient groups. J. Eukaryot. Microbiol. 2009, 56, 388-393. [CrossRef] [PubMed]

153. Lanternier, F.; Boutboul, D.; Menotti, J.; Chandesris, M.O.; Sarfati, C.; Mamzer Bruneel, M.F.; Calmus, Y.; Mechaï, F.; Viard, J.P.; Lecuit, M.; et al. Microporidiosis in solid organ transplant recipients: Two Enterocytozoon bieneusi cases and review. Transpl. Infect. Dis. 2009, 11, 83-88. [CrossRef] [PubMed]

154. Champion, L.; Durrbach, A.; Lang, P.; Delahousse, M.; Chauvet, C.; Sarfati, C.; Glotz, D.; Molina, J.M. Fumagillin for treatment of intestinal microsporidiosis in renal transplant recipients. Am. J. Transplant. 2010, 10, 1925-1930. [CrossRef] [PubMed]

155. Talabani, H.; Talabani, H.; Sarfati, C.; Pillebout, E.; van Gool, T.; Derouin, F.; Menotti, J. Disseminated infection with a new genovar of Encephalitozoon cuniculi in a renal transplant recipient. J. Clin. Microbiol. 2010, 48, 2651-2653. [CrossRef] [PubMed]

156. Galvan, A.L.; Martin Sanchez, A.M.; Perez Valentin, M.A.; Henriques-Gil, N.; Izquierdo, F.; Fenoy, S.; del Aguila, C. First cases of microsporidiosis in transplant recipients in Spain and review of the literature. J. Clin. Microbiol. 2011, 49, 1301-1306. [CrossRef] [PubMed]

157. Field, A.S.; Paik, J.Y.; Stark, D.; Qiu, M.R.; Morey, A.; Plit, M.L.; Canning, E.U.; Glanville, A.R. Myositis due to the microsporidian Anncaliia (Brachiola) algerae in a lung transplant recipient. Transpl. Infect. Dis. 2012, 14, 169-176. [CrossRef] [PubMed]

158. Bednarska, M.; Bajer, A.; Welc-Faleciak, R.; Sinski, E. The first case of Enterocytozoon bieneusi infection in Poland. Ann. Agric. Environ. Med. 2013, 20, 287-288. [PubMed]

159. Nagpal, A.; Pritt, B.S.; Lorenz, E.C.; Amer, H.; Nasr, S.H.; Cornell, L.D.; Iqbal, S.; Wilhelm, M.P. Disseminated microsporidiosis in a renal transplant recipient: Case report and review of the literature. Transpl. Infect. Dis. 2013, 15, 526-532. [CrossRef] [PubMed] 
160. Kicia, M.; Wesolowska, M.; Jakuszko, K.; Kopacz, Z.; Sak, B.; Květonova, D.; Kvac, M. Concurrent infection of the urinary tract with Encephalitozoon cuniculi and Enterocytozoon bieneusi in a renal transplant recipient. J. Clin. Microbiol. 2014, 52, 1780-1782. [CrossRef] [PubMed]

161. Palau, L.A.; Pankey, G.A. Strongyloides hyperinfection in a renal transplant recipient receiving cyclosporine: Possible Strongyloides stercoralis transmission by kidney transplant. Am. J. Trop. Med. Hyg. 1997, 57, 413-415. [CrossRef] [PubMed]

162. Soman, R.; Vaideeswar, P.; Shah, H.; Almeida, A.F. A 34-year-old renal transplant recipient with highgrade fever and progressive shortness of breath. J. Postgrad. Med. 2002, 48, 191-196. [PubMed]

163. Tarr, P.; Miele, P.S.; Peregoy, K.S.; Smith, M.A.; Neva, F.A.; Lucey, D.R. Case report: Rectal administration of ivermectin to a patient with Strongyloides hyperinfection syndrome. Am. J. Trop. Med. Hyg. 2003, 68, 453-455. [PubMed]

164. Schaeffer, M.W.; Buell, J.F.; Gupta, M.; Conway, G.D.; Akhter, S.A.; Wagoner, L.E. Strongyloides hyperinfection syndrome after heart transplantation: Case report and review of the literature. J. Heart Lung Transplant. 2004, 23, 905-911. [CrossRef] [PubMed]

165. Ben-Youssef, R.; Baron, P.; Edson, F.; Raghavan, R.; Okechukwu, O. Strongyloides stercoralis infection from pancreas allograft: Case report. Transplantation 2005, 80, 997-998. [CrossRef] [PubMed]

166. El Masry, H.Z.; O'Donnell, J. Fatal Strongyloides hyperinfection in heart transplantation. J. Heart Lung Transplant. 2005, 24, 1980-1983. [CrossRef] [PubMed]

167. Prasad, N.; Ram, R.; Satti Reddy, V.; Dakshinamurty, K.V. Non-fatal gastric mucormycosis in a renal transplant patient and review of the literature. Transpl. Infect. Dis. 2006, 8, 237-241. [CrossRef] [PubMed]

168. Said, T.; Nampoory, M.R.; Nair, M.P.; Halim, M.A.; Shetty, S.A.; Kumar, A.V.; Mokadas, E.; Elsayed, A.; Johny, K.V.; Samhan, M.; et al. Hyperinfection strongyloidiasis: An anticipated outbreak in kidney transplant recipients in Kuwait. Transplant. Proc. 2007, 39, 1014-1015. [CrossRef] [PubMed]

169. Lichtenberger, P.; Rosa-Cunha, I.; Morris, M.; Nishida, S.; Akpinar, E.; Gaitan, J.; Tzakis, A.; Doblecki-Lewis, S. Hyperinfection strongyloidiasis in a liver transplant patient treated with parenteral ivermectin. Transpl. Infect. Dis. 2009, 11, 137-142. [CrossRef] [PubMed]

170. Morrell, M.R.; Dallas, J.; Kollef, M.H. A 50-year-old woman with abdominal pain and respiratory failure 3 months after kidney transplantation. Chest 2008, 134, 442-446. [CrossRef] [PubMed]

171. Patel, G.; Arvelakis, A.; Sauter, B.V.; Gondolesi, G.E.; Caplivski, D.; Huprikar, S. Strongyloides hyperinfection syndrome after intestinal transplantation. Transpl. Infect. Dis. 2008, 10, 137-141. [CrossRef] [PubMed]

172. Vilela, E.G.; Clemente, W.T.; Mira, R.R.; Torres, H.O.; Veloso, L.F.; Fonseca, L.P.; de Carvalho E Fonseca, L.R.; Franca, M.d.; Lima, A.S. Strongyloides stercoralis hyperinfection syndrome after liver transplantation: Case report and literature review. Transpl. Infect. Dis. 2009, 11, 132-136. [CrossRef] [PubMed]

173. Balagopal, A.; Mills, L.; Shah, A.; Subramanian, A. Detection and treatment of Strongyloides hyperinfection syndrome following lung transplantation. Transpl. Infect. Dis. 2009, 11, 149-154. [CrossRef] [PubMed]

174. Beltrán Catalán, S.; Crespo Albiach, J.F.; Morales García, A.I.; Gavela Martínez, E.; Górriz Teruel, J.L.; Pallardó Mateu, L.M. Strongyloides stercoralis infection in renal transplant recipients. Nefrologia 2009, 29, 482-485. [CrossRef] [PubMed]

175. Huston, J.M.; Eachempati, S.R.; Rodney, J.R.; Cayci, C.; Fusco, D.; Mathew, M.; Shou, J.; Goldstein, M.J.; Kapur, S.; Barie, P.S. Treatment of Strongyloides stercoralis hyperinfection-associated septic shock and acute respiratory distress syndrome with drotrecogin ALFA (Activated) in a renal transplant recipient. Transpl. Infect. Dis. 2009, 11, 277-280. [CrossRef] [PubMed]

176. Mizuno, S.; Lida, T.; Zendejas, I.; Martin, T.D.; Schain, D.C.; Turner, B.; Fujita, S. Strongyloides hyperinfection syndrome following simultaneous heart and kidney transplantation. Transpl. Int. 2009, 22, 251-253. [CrossRef] [PubMed]

177. Mokaddas, E.M.; Shati, S.; Abdulla, A.; Nampoori, N.R.; Iqbal, J.; Nair, P.M.; Said, T.; Abdulhalim, M.; Hira, P.R. Fatal strongyloidiasis in three kidney recipients in Kuwait. Med. Princ. Pract. 2009, 18, 414-417. [CrossRef] [PubMed]

178. Rodriguez-Hernandez, M.J.; Ruiz-Perez-Pipaon, M.; Cañas, E.; Bernal, C.; Gavilan, F. Strongyloides stercoralis hyperinfection transmitted by liver allograft in a transplant recipient. Am. J. Transplant. 2009, 9, 2637-2940. [CrossRef] [PubMed]

179. Roxby, A.C.; Gottlieb, G.S.; Limaye, A.P. Strongyloidiasis in transplant patients. Clin. Infect. Dis. 2009, 49, 1411-14123. [CrossRef] [PubMed] 
180. Brügemann, J.; Kampinga, G.A.; Riezebos-Brilman, A.; Stek, C.J.; Edel, J.P.; van der Bij, W.; Sprenger, H.G.; Zijlstra, F. Two donor-related infections in a heart transplant recipient: One common, the other a tropical surprise. J. Heart Lung Transplant. 2010, 29, 1433-1437. [CrossRef] [PubMed]

181. Hamilton, K.W.; Abt, P.L.; Rosenbach, M.A.; Bleicher, M.B.; Levine, M.S.; Mehta, J.; Montgomery, S.P.; Hasz, R.D.; Bono, B.R.; Tetzlaff, M.T.; et al. Donor-derived Strongyloides stercoralis infections in renal transplant recipients. Transplantation 2011, 91, 1019-1024. [CrossRef] [PubMed]

182. Weiser, J.A.; Scully, B.E.; Bulman, W.A.; Husain, S.; Grossman, M.E. Periumbilical parasitic thumbprint purpura: Strongyloides hyperinfection syndrome acquired from a cadaveric renal transplant. Transpl. Infect. Dis. 2011, 13, 58-62. [CrossRef] [PubMed]

183. Hsu, C.N.; Tseng, S.H.; Chang, S.W.; Chen, Y. Strongyloides stercoralis infection in an intestinal transplant recipient. Transpl. Infect. Dis. 2013, 15, e139-e143. [CrossRef] [PubMed]

184. Roseman, D.A.; Kabbani, D.; Kwah, J.; Bird, D.; Ingalls, R.; Gautam, A.; Nuhn, M.; Francis, J.M. Strongyloides stercoralis transmission by kidney transplantation in two recipients from a common donor. Am. J. Transplant. 2013, 13, 2483-2486. [CrossRef] [PubMed]

185. Sadjadi, S.A.; Damodaran, C.; Sharif, M. Strongyloides stercoralis infection in transplanted patients. Am. J. Case Rep. 2013, 14, 205-209. [CrossRef] [PubMed]

186. Khuroo, M.S. Hyperinfection strongyloidiasis in renal transplant recipients. BMJ Case Rep. 2014, 2014, bcr2014205068. [CrossRef] [PubMed]

187. Le, M.; Ravin, K.; Hasan, A.; Clauss, H.; Muchant, D.G.; Pasko, J.K.; Cipollina, G.; Abanyie, F.; Montgomery, S.P.; Loy, M.; et al. Single donor-derived strongyloidiasis in three solid organ transplant recipients: Case series and review of the literature. Am. J. Transplant. 2014, 14, 1199-1206. [CrossRef] [PubMed]

188. Abanyie, F.A.; Gray, E.B.; Delli Carpini, K.W.; Yanofsky, A.; McAuliffe, I.; Rana, M.; Chin-Hong, P.V.; Barone, C.N.; Davis, J.L.; Montgomery, S.P.; et al. Donor-derived Strongyloides stercoralis infection in solid organ transplant recipients in the United States, 2009-2013. Am. J. Transplant. 2015, 15, 1369-1375. [CrossRef] [PubMed]

189. Abdalhamid, B.A.; Al Abadi, A.N.; Al Saghier, M.I.; Joudeh, A.A.; Shorman, M.A.; Amr, S.S. Strongyloides stercoralis infection in kidney transplant recipients. Saudi J Kidney Dis. Transpl. 2015, 26, 98-102. [CrossRef] [PubMed]

190. Galiano, A.; Trelis, M.; Moya-Herráiz, Á.; Sánchez-Plumed, J.; Merino, J.F. Donor-derived Strongyloides stercoralis hyperinfection syndrome after simultaneouskidney/pancreas transplantation. Int. J. Infect. Dis. 2016, 51, 19-21. [CrossRef] [PubMed]

191. Gómez-Junyent, J.; Paredes-Zapata, D.; de las Parras, E.R.; González-Costello, J.; Ruiz-Arranz, Á.; Cañizares, R.; Cañizares, R.; Saugar, J.M.; Muñoz, J. Real-Time Polymerase Chain Reaction in Stool Detects Transmission of Strongyloides stercoralis from an Infected Donor to Solid Organ Transplant Recipients. Am. J. Trop. Med. Hyg. 2016, 94, 897-899. [CrossRef] [PubMed]

192. Huang, N.C.; Fang, H.C.; Chou, K.J.; Chung, H.M. Trichuris trichiura: An unusual cause of chronic diarrhoea in a renal transplant patient. Nephrol. Dial. Transplant. 2003, 18, 2434-2435. [CrossRef] [PubMed]

193. Sunil, P.; Tribhuvan, G.; Anil, M. Ascariasis as a cause of obstructive jaundice in a renal transplant patient. J. Nephrol. 2004, 17, 449-451. [PubMed]

194. Sahin, I.; Köz, S.; Atambay, M.; Kayabas, U.; Piskin, T.; Unal, B. A rare cause of diarrhea in a kidney transplant recipient: Dipylidium caninum. Transplant. Proc. 2015, 47, 2243-2244. [CrossRef] [PubMed]

195. Valencia, V.B.; Elola-Olaso, A.M.; Suárez, Y.F.; Díaz, J.C.M.; de los Galanes, S.F.J.; Saborido, B.P.; San Juan, R.; Giménez, J.R.; Abradelo Usera, M.; Donat Garrido, M.; et al. Second case of neurocysticercosis in a patient with liver transplantation (first case in Spain): A case report. Transplant. Proc. 2007, 39, 2454-2457. [CrossRef] [PubMed]

196. Hoare, M.; Gelson, W.T.; Antoun, N.; Alexander, G.J. Early recurrence of neurocysticercosis after orthotopic liver transplant. Liver Transplant. 2006, 12, 490-491. [CrossRef] [PubMed]

197. Hoare, M.; Gelson, W.T.H.; Davies, S.E.; Curran, M.; Alexander, G.J.M. Hepatic and Intestinal Schistosomiasis after Orthotopic Liver Transplant. Liver Transplant. 2005, 11, 1603-1607. [CrossRef] [PubMed] 
198. Vincenzi, R.; Neto, J.S.; Fonseca, E.A.; Pugliese, V.; Leite, K.R.; Benavides, M.R.; Benavides, M.R.; Cândido, H.L.; Porta, G.; Miura, I.K.; et al. Schistosoma mansoni infection in the liver graft: The impact on donor and recipient outcomes after transplantation. Liver Transplant. 2011, 17, 1299-1303. [CrossRef] [PubMed]

199. Bresson-Hadni, S.; Koch, S.; Beurton, I.; Vuitton, D.A.; Bartholomot, B.; Hrusovsky, S.; Heyd, B.; Lenys, D.; Minello, A.; Becker, M.C.; et al. Primary disease recurrence after liver transplantation for alveolar echinococcosis: Long-term evaluation in 15 patients. Hepatology 1999, 30, 857-864. [CrossRef] [PubMed]

200. Mosimann, F.; Bettschart, V.; Meuli, R. Mediastinal recurrence of alveolar echinococcosis after liver transplantation. Liver Transplant. 2003, 9, 97-98. [CrossRef] [PubMed]

201. Sqalli, T.H.; Buchler, M.; Al Najjar, A.; Paris, A.; Halimi, J.M.; Nivet, H.; Anthonioz, P.; Bourlier, P.; Duong, T.H.; Lebranchu, Y. Hydatid cyst disease in a renal allograft recipient. Saudi J Kidney Dis. Transpl. 2009, 20, 1057. [PubMed]

202. Palmiero, G.; Ciampi, R.; Gallo, R.; Federico, S.; Sabbatini, M. Liver echinococcosis in a renal transplant patient: A particularly intriguing case report. J. Nephrol. 2008, 21, 442. [PubMed]

203. Geyer, M.; Wilpert, J.; Wiech, T.; Theilacker, C.; Stubanus, M.; Kramer-Zucker, A.; Fischer, K.G.; Drognitz, O.; Frydrychowicz, A.; Kern, W.; et al. Rapidly progressive hepatic alveolar echinococcosis in an ABO-incompatible renal transplant recipient. Transpl. Infect. Dis. 2011, 13, 278-284. [CrossRef] [PubMed]

204. Fabiani, S.; Fortunato, S.; Petrini, M.; Bruschi, F. Allogeneic haematopoietic stem cell transplant recipients and parasitic diseases: A review of the literature of clinical cases and perspectives to screen and follow-up active and latent chronic infections. Transpl. Infect. Dis. 2017, 19. [CrossRef] [PubMed]

205. Mosti, M.; Pinto, B.; Giromella, A.; Fabiani, S.; Cristofani, R.; Panichi, M.; Bruschi, F. A 4-year evaluation of toxoplasmosis seroprevalence in the general population and in women of reproductive age in central Italy. Epidemiol. Infect. 2013, 141, 2192-2195. [CrossRef] [PubMed]

206. Pinto, B.; Mattei, R.; Moscato, G.A.; Cristofano, M.; Giraldi, M.; Scarpato, R.; Buffolano, W.; Bruschi, F. Toxoplasma infection in individuals in central Italy: Does a gender-linked risk exist? Eur. J. Clin. Microbiol. Infect. Dis. 2016, 36, 739-746. [CrossRef] [PubMed]

207. Robert-Gangneux, F.; Amrein, C.; Lavarde, V.; Botterel, F.; Dupouy-Camet, J. Neosynthesized IgG detected by western blotting in Toxoplasma-seropositive heart or lung transplant recipients. Transpl. Int. 2000, 13, 448-452. [CrossRef] [PubMed]

208. Dardé, M.L.; Aubert, D.; Derouin, F.; Dumetre, A.; Pelloux, H.; Villena, I. Toxoplasma gondii. In Emerging Protozoan Pathogens; Khan, N., Ed.; Taylor and Francis: London, UK, 2007; pp. 227-287.

209. Morisset, S.; Peyron, F.; Lobry, J.R.; Garweg, J.; Ferrandiz, J.; Musset, K.; Gomez-Marin, J.E.; de la Torre, A.; Demar, M.; Carme, B.; et al. Serotyping of Toxoplasma gondii: Striking homogeneous pattern between symptomatic and asymptomatic infections within Europe and South America. Microbes. Infect. 2008, 10, 742-747. [CrossRef] [PubMed]

210. Liu, Q.; Wang, Z.D.; Huang, S.-Y.; Zhu, X.-Q. Diagnosis of toxoplasmosis and typing of Toxoplasma gondii. Parasite Vectors 2015, 8, 292-305. [CrossRef] [PubMed]

211. Karras, A.; Thervet, E.; Legendre, C.; Groupe Cooperatif de transplantation D'Ile de France. Hemophagocytic syndrome in renal transplant recipients: Report of 17 cases and review of literature. Transplantation 2004, 77, 238-243. [CrossRef] [PubMed]

212. Walker, M.; Zunt, J.R. Parasitic central nervous system infections in immonocompromised hosts. Clin. Infect. Dis. 2005, 40, 1005-1015. [CrossRef] [PubMed]

213. Moshfeghi, D.M.; Dodds, E.M.; Couto, C.A.; Santos, C.I.; Nicholson, D.H.; Lowder, C.Y.; Davis, J.L. Diagnostic approaches to severe, atypical toxoplasmosis mimicking acute retinal necrosis. Ophthalmology 2004, 111, 716-725. [CrossRef] [PubMed]

214. Munir, A.; Zaman, M.; Eltorky, M. Toxoplasma gondii pneumonia in a pancreas transplant patient. South. Med. J. 2000, 93, 614-617. [CrossRef] [PubMed]

215. Contini, C.; Cultrera, R.; Seraceni, S.; Segala, D.; Romani, R.; Fainardi, E.; Cinque, P.; Lazzarin, A.; Delia, S. The role of stage-specific oligonucleotide primers in providing effective laboratory support for the molecular diagnosis of reactivated Toxoplasma gondii encephalitis in patients with AIDS. J. Med. Microbiol. 2002, 51, 879-890. [CrossRef] [PubMed] 
216. Chapey, E.; Wallon, M.; Debize, G.; Rabilloud, M.; Peyron, F. Diagnosis of Congenital Toxoplasmosis by Using a Whole-Blood Gamma Interferon Release Assay. J. Clin. Microbiol. 2010, 48, 41-45. [CrossRef] [PubMed]

217. Montoya, J.G.; Giraldo, L.F.; Efron, B.; Stinson, E.B.; Gamberg, P.; Hunt, S.; Giannetti, N.; Miller, J.; Remington, J.S. Infectious complications among 620 consecutive heart transplant patients at Stanford University Medical Center. Clin. Infect. Dis. 2001, 33, 629-640. [CrossRef] [PubMed]

218. Baden, L.R.; Katz, J.T.; Franck, L.; Tsang, S.; Hall, M.; Rubin, R.H.; Jarcho, J. Successful toxoplasmosis prophylaxis after orthotopic cardiac transplantation with trimethoprim-sulfamethoxazole. Transplantation 2003, 75, 339-343. [CrossRef] [PubMed]

219. Antinori, S.; Cascio, A.; Parravicini, C.; Bianchi, R.; Corbellino, M. Leishmaniasis among organ transplant recipients. Lancet Infect. Dis. 2008, 8, 191-199. [CrossRef]

220. Bonney, K.M. Chagas disease in the 21st century: A public health success or an emerging threat? Parasite 2014, 21, 11. [CrossRef] [PubMed]

221. Bestetti, R.B.; Theodoropoulos, T.A. A systematic review of studies on heart transplantation for patients with end-stage Chagas' heart disease. J. Card. Fail. 2009, 15, 249-255. [CrossRef] [PubMed]

222. Diez, M.; Favaloro, L.; Bertolotti, A.; Burgos, J.M.; Vigliano, C.; Lastra, M.P.; Levin, M.J.; Arnedo, A.; Nagel, C.; Schijman, A.G.; et al. Usefulness of PCR strategies for early diagnosis of Chagas' disease reactivation and treatment follow-up in heart transplantation. Am. J. Transplant. 2007, 7, 1633-1640. [CrossRef] [PubMed]

223. Belhadj, K.; Reyes, F.; Farcet, J.P.; Tilly, H.; Bastard, C.; Angonin, R.; Deconinck, E.; Charlotte, F.; Leblond, V.; Labouyrie, E.; et al. Hepatosplenic gammadelta T-cell lymphoma is a rare clinicopathologic entity with poor outcome: Report on a series of 21 patients. Blood 2003, 102, 4261-4269. [CrossRef] [PubMed]

224. Barsoum, R.S. Malarial acute renal failure. J. Am. Soc. Nephrol. 2000, 11, 2147-2154. [PubMed]

225. Eda, K.; Eda, S.; Sherman, I.W. Identification of peptides targeting the surface of Plasmodium falciparum-infected erythrocytes using a phage display peptide library. Am. J. Trop. Med. Hyg. 2004, 71, 190-195. [PubMed]

226. Hanscheid, T.; Grobusch, M.P. How useful is PCR in the diagnosis of malaria? Trends Parasitol. 2002, 18, 395-398. [CrossRef]

227. Anteyi, E.A.; Liman, H.M.; Gbaji, A. Malaria prophylaxis in post renal transplant recipients in the tropics: Is it necessary? Cent. Afr. J. Med. 2003, 49, 63-66. [PubMed]

228. Veletzky, L.; Rehman, K.; Lingscheid, T.; Poeppl, W.; Loetsch, F.; Burgmann, H.; Ramharter, M. In vitro activity of immunosuppressive drugs against Plasmodium falciparum. Malar. J. 2014, 13, 476. [CrossRef] [PubMed]

229. Giacomini, T. Malaria in airports and their neighborhoods. Rev. Prat. 1998, 48, 264-267. [PubMed]

230. Piperaki, E.T.; Mavrouli, M.; Tseroni, M.; Routsias, J.; Kallimani, A.; Veneti, L.; Georgitsou, M.; Chania, M.; Georgakopoulou, T.; Hadjichristodoulou, C.; et al. Assessment of antibody responses in local and immigrant residents of areas with autochthonous malaria transmission in Greece. Am. J. Trop. Med. Hyg. 2015, 93, 153-158. [CrossRef] [PubMed]

231. Visvesvara, G.S.; Moura, H.; Schuster, F.L. Pathogenic and opportunistic free-living amoebae: Acanthamoeba spp., Balamuthia mandrillaris, Naegleria fowleri, and Sappinia diploidea. FEMS Immunol. Med. Microbiol. 2007, 50, 1-26. [CrossRef] [PubMed]

232. Danziger-Isakov, L. Gastrointestinal infections after transplantation. Curr. Opin. Gastroenterol. 2014, 30, 40-46. [CrossRef] [PubMed]

233. Rice, J.P.; Spier, B.J.; Cornett, D.D.; Walker, A.J.; Richie, K.; Pfau, P.R. Utility of colonoscopy in the evaluation of diarrhea in solid organ transplant recipients. Transplantation 2009, 88, 374-379. [CrossRef] [PubMed]

234. Singh, N.; Husain, S. Infections of the central nervous system in transplant recipients. Transpl. Infect. Dis. 2000, 2, 101-111. [CrossRef] [PubMed]

235. Ross, A.G.; Bartley, P.B.; Sleigh, A.C.; Olds, G.R.; Li, Y.; Williams, G.M.; McManus, D.P. Schistosomiasis. N. Engl. J. Med. 2002, 346, 1212-1220. [CrossRef] [PubMed]

236. Barrou, B.; Bitker, M.O.; Boyer, C.; Sylla, C.; Chatelain, C. Results of renal transplantation in patients with Schistosoma infection. J. Urol. 1997, 157, 1232-1235. [CrossRef]

237. Cooper, A.J.R.; Dholakia, S.; Holland, C.V.; Friend, P.J. Helminths in organ transplantation. Lancet Infect. Dis. 2017, 17, e166-e176. [CrossRef] 
238. Rzepecka, J.; Harnett, W. Can the Study of Helminths Be Fruitful for Human Diseases? In Helminth Infections and Their Impact on Global Public Health; Bruschi, F., Ed.; Springer: Wien, Austria, 2014; pp. 479-502.

239. Deng, G.; Deng, R.; Yao, J.; Liao, B.; Chen, Y.; Wu, Z.; Hu, H.; Zhou, X.; Ma, Y. Trichinella spiralis infection changes immune response in mice performed abdominal heterotopic cardiac transplantation and prolongs cardiac allograft survival time. Parasitol. Res. 2015, 115, 407-414. [CrossRef] [PubMed]

240. Elliott, D.E.; Weinstock, J.V. Nematodes and human therapeutic trials for inflammatory disease. Parasit. Immunol. 2017, 39. [CrossRef] [PubMed]

241. Bager, P.; Kapel, C.; Roepstorff, A.; Thamsborg, S.; Arnved, J.; Rønborg, S.; Kristensen, B.; Poulsen, L.K.; Wohlfahrt, J.; Melbye, M. Symptoms after ingestion of pig whipworm Trichuris suis eggs in a randomized placebo-controlled double-blind clinical trial. PLoS ONE 2011, 6, e22346. [CrossRef] [PubMed]

(C) 2018 by the authors. Licensee MDPI, Basel, Switzerland. This article is an open access article distributed under the terms and conditions of the Creative Commons Attribution (CC BY) license (http:// creativecommons.org/licenses/by/4.0/). 